\title{
Skrift og språk som identitetsuttrykk i graffiti fra norske kirker i middelalderen*
}

\author{
Av Karen Langsholt Holmqvist
}

Artikkelen drøfter graffiti med runer og bokstaver i norske middelalderkirker og ser skrifttype og språk som to variabler for risteres selvuttrykk. Som eksempel brukes innskrifter fra Hopperstad og Borgund stavkirker. Hopperstad har kun runeinnskrifter, som er både tematisk og romlig fordelt i kirkerommet. I koret finner vi formelpregede religiøse ytringer på latin; i skipet folkespråklige innskrifter som er varierte og leserorienterte, med både lek og religiøse uttrykk. Risterne vender seg til det sosiale fellesskapet og mot kirkebygget som religiøst samlingspunkt. Borgund er kjennetegnet av svært skriftkyndige ristere som bruker både dekorerte runer og bokstaver for å skape tekstlige og visuelle effekter i innskriftene. Artikkelen presenterer flere nyfunn av minuskler herfra, og disse sammenliknes med bokstavinnskrifter, særlig med minuskler, i andre kirker i Norge og Danmark, og tolkes som mulige religiøse uttrykk. Samtidig kan minusklene også være ristet som $\varnothing$ velse eller dekorasjon, og de kan dermed ha flere lag av betydning.

* Mye av feltarbeidet som ligger til grunn for denne artikkelen, er gjort sammen med stipendiat Johan Bollaert, og omtaler av bokstavinnskriftene er basert på diskusjon og samtaler med ham. Takk til Fortidsminneforeningen, som har gitt oss adgang til Borgund og Hopperstad. Jeg vil også takke fagfellene og redaktør Ingvil Brügger Budal for gode og konstruktive tilbakemeldinger på artikkelen. Takk til veiledere, Stefka G. Eriksen, Karl G. Johansson og Kristel Zilmer, og til Johan Bollaert, for tilbakemeldinger på tidligere utkast til artikkelen. En spire til artikkelen ble også presentert for Kunnskapssystem-gruppa ved UiO, bestående av veiledere og stipendiater i middelalderhistorie, kunsthistorie og norrøn filologi. Takk også til denne gruppa for gode innspill, og til kollegaer ved NIKU som ved ulike anledninger har svart på spørsmål om blant annet stavkirker, Maria-altre og kirkekunst. Til sist går en stor takk til James E. Knirk og Kristel Zilmer ved Runearkivet ved Kulturhistorisk museum i Oslo, som ved ulike anledninger har hentet ut informasjon til meg fra $\mathrm{Ru}$ nearkivet. 


\section{Innledning}

I mange kirker fra middelalderen finnes uformelle innskrifter med runer og bokstaver; ${ }^{1}$ disse er en verdifull kilde til hvordan mennesker i middelalderen oppfattet seg selv. Flere har vært opptatt av runeinnskrifter i kirkene, men de blir sjelden sett i sammenheng med bokstavinnskrifter i de samme kirkene. Denne artikkelen analyserer skriftform og språk i innskriftene og viser hvordan ristere tar bevisste valg for å nå fram med budskapet sitt og oppnå ulike effekter i innskriftene. Skrift kan brukes som pynt, til å gi informasjon om motivene $i$ et maleri, til å fortelle hvem som bygde kirka og hvem som fikk den bygd. Men skrift i kirkerommet er også bønner, uttrykk for hengivenhet og henvendelser til Gud, Maria og helgener, personlige signaturer, skriftopplæring og skriftlek. I det følgende vil jeg presentere de uformelle skriftuttrykkene på bygningskonstruksjonene i kirka, altså vegger, søyler osv. Jeg diskuterer om skriftform og språk - runer og bokstaver, folkespråk og latin - kan forstås som uttrykk for risternes selv, og vil drøfte hva disse variablene kan fortelle om risternes selvforståelse.

Målet med artikkelen er å drøfte hva uformelle kirkeinnskrifter fra middelalderen kan fortelle om risternes selvforståelse. Artikkelen tar utgangspunkt i to eksempelkirker: Hopperstad og Borgund stavkirker. Disse kirkene er valgt fordi de har eksempler på alle de vanlige gruppene med kirkegraffiti, og de er blant kirkene i Norge med flest runeinnskrifter. Samtidig er også mye ulikt i de to kirkene, og dette gjør også at fokus blir ulikt i de to delene av artikkelen. For Hopperstad drøfter jeg bruken av latin og folkespråk, og jeg argumenterer for at mange av runeinnskriftene knytter individene opp mot menigheten og skaper et religiøst fellesskap. Videre argumenterer jeg for at man finner elementer av lek og skriftopplæring i runeinnskriftene. I Borgund stavkirke har flere ristere tilsynelatende lekt og eksperimentert med skriftformer. Jeg drøfter først hvordan dekorative elementer flettes inn i noen runeinnskrifter og re-

1. Jeg vil omtale "latinske bokstaver" kun som "bokstaver". Dette er i samsvar med etymologien til ordet; i tekster fra middelalderen skilte man gjerne mellom bókstafir og rúnastafir. Jeg bruker ordet "innskrift" for å omtale tekstsekvenser med både bokstaver og runer, og bruker ordet som en generell term for å omfatte både rune- og bokstavinnskrifter. Dersom jeg sikter til bare én av typene, vil dette gå klart fram i teksten. Innskriftene jeg omtaler i denne artikkelen, er i hovedsak uformelle. Hva jeg legger i dette, kommer jeg tilbake til i avsnitt 3 . 
flekterer risternes inngående kjennskap til runeskriften. Deretter løfter jeg fram flere nyfunn av minuskler på kirkeveggene og drøfter om de kan forstås som religiøse eller dekorative uttrykk, eller om de kan være skrift $\varnothing v e l s e r$. Artikkelen vil bidra med ny innsikt i de uformelle skriftpraksisene i kirker i middelalderen, og vil videre gi et innblikk i hvordan individet forstår seg selv i møte med kirkerommet. Dette kan $\varnothing$ ke forståelsen vår for handlingene som har foregått i kirkerommet og for mer folkelige religiøse praksiser.

\section{Tidligere forskning på kirkeinnskrifter}

Mens uformelle bokstavinnskrifter i liten grad er samlet inn og studert, ${ }^{2}$ er runeinnskrifter mye bredere studert og omtalt. Flertallet av de kjente og registrerte norske kirkeinnskriftene med runer er samlet i Norges innskrifter med de yngre runer (NIyR), og for brorparten av disse står lesningene og tolkningene som Olsen og Liest $\varnothing 1$ presenterte, fortsatt. Beskrivelsene i NIyR er også viktige fordi menneskehender, vær og vind har slitt på mange innskrifter de seinere årene. Andre innskrifter er vanskelig tilgjengelige fordi de er beskyttet bak glass eller skjult bak nye bygningskonstruksjoner. Dermed er de grundige beskrivelsene og dokumentasjonen i NIyR, sammen med de underliggende dokumentasjonsog forskningsarkivaliene ved Kulturhistorisk museum (KHM) ved Universitetet i Oslo (UiO), fortsatt et viktig fundament for all ny forskning på norske kirkeinnskrifter. ${ }^{3}$ Samtidig har det kommet flere nye og viktige bidrag til forskningen de siste årene.

Spurkland viser i en gjennomgang av kirkeinnskriftene at man i stor grad finner de samme innskriftene både i og utenfor kirkene i middelalderen, og han mener derfor at kirkeinnskriftene ikke kan defineres som en egen sjanger (2001: 178). Likevel er det naturlig å diskutere og definere

2. To viktige unntak er Nidarosdomen (se Holmqvist 2019; Syrett 2002) og Johan Bollaerts kommende doktoravhandling, som tar for seg innskrifter fra hele Norge og også inkluderer en del graffiti.

3. I tillegg er flere nyfunn av innskrifter og rettelser og omvurderinger blitt publisert $\mathrm{i}$ Nytt om runer og i egne artikler. Dette gjelder blant annet innskriftene fra B $\varnothing$ gamle kirke (Knirk 1986) og fire innskrifter fra Borgund: N A297 (Nytt om runer 3 1988) og N A307-o9 (Nytt om runer 4 1989). Også denne typen kilder er et viktig grunnlag for videre forskning. 
kirkeinnskriftene som ei egen materialgruppe, slik Spurkland også gjør. Barnes har samme skille, og han skiller i tillegg mellom formelle innskrifter (2012: 100-104) og graffiti (2012: 116-119) i kirkene. Jones (2010) gir innblikk i hvordan innskriftene i kirker fordeler seg både geografisk i Norge og i kirkerommet i kirkene, og sannsynliggjør at innskriftene har blitt ristet over tid, og ikke nødvendigvis rett etter at kirkene ble bygget, slik blant annet Blindheim (1985: 13-16) har hevdet. Videre har Zilmer (2016) vist hvordan det offentlige og private, det autoriserte og uautoriserte, og det seremonielle og uformelle flyter over i hverandre og spiller sammen i runeinnskrifter i de norske middelalderkirkene. Hun ser spesielt på hva innskriftene forteller om bruken av runer i kirkene, og konkluderer med at et bredt spekter av mennesker ristet runer i kirkene: både lokale og tilreisende, kvinner og menn, prester, aristokratiet, sponsorer, byggherrer, andre som var med i byggeprosessen, og vanlige kirkegjengere har ristet innskrifter i kirkene. Zilmer argumenterer også for at kirkeinnskriftene har kommet til over et langt tidsrom, og for at de var aksepterte og en naturlig del av mange kirker. Ikke minst viser Zilmer at risterne gjennom innskriftene knytter seg selv til kirka, og at det å riste en innskrift i kirkebygget slik blir en religiøs handling.

Det er også gjort mer inngående studier av enkeltkirker. Jeg har tidligere (Holmqvist 2018) diskutert selvet i middelalderinnskriftene med runer og bokstaver i Nidarosdomen. Med utgangspunkt i kognitiv teori viser jeg hvordan innskriftene der først og fremst er uttrykk for en religiøs identitet blant risterne, samtidig som enkelte ristere også brukte kirkeveggene til andre identitetsuttrykk. Zilmer (under publisering) tar for seg ulike identitetsuttrykk i innskrifter fra middelalderen, og inkluderer blant annet en casestudie av runeinnskriftene i Lom stavkirke. Her viser hun hvordan innskriftene kan ses som en synkron og diakron samhandling mellom ristere fra ulike samfunnslag gjennom flere århundrer. Studiene av innskrifter i enkeltkirker forsterker altså inntrykket av at kirkeinnskriftene er en naturlig del av middelalderkirkene og at det å riste innskrifter i kirka kunne oppfattes som en religiøs handling. Tilsvarende bruk av runer i kirkene finnes også i Sverige (Gustavson 1991; Källström 2016; Lerche Nielsen 2019; Pernler 1994) og Danmark (Imer 2018: 80-86; Moltke 1985: 426-441) og ellers i den kristne verden, for eksempel i middelalderens Novgorod (Rozhdestvenskaja 2012) ved tidlige kristne hellige steder (Yasin 2015), i Monte Sant'Angelo i Italia (Wal- 
dispühl 2019), i engelske middelalderkirker (Champion 2016), og på tilholdssteder for koptiske munker i Egypt (Goehring 2015; Lundhaug \& Jenott 2015: 39-42). Det er altså stor konsensus i dag om at de fleste historiske innskrifter i kirkene og på andre hellige steder kan forstås som religiøse ytringer, og dette vil ligge som et premiss for denne artikkelen.

Her vil jeg se runeinnskriftene i sammenheng med bokstavinnskrifter. Der tidligere studier i stor grad har sett på innholdet i innskriftene når de diskuterer risternes identitetsuttrykk, vil jeg unders $\emptyset$ ke variablene språk og skrifttype. Jeg legger vekt på to enkeltkirker - Hopperstad og Borgund - for å kunne gå dypere inn i materialet, men jeg henter også eksempler fra andre kirker for å sette materialet i en st $\varnothing$ rre kontekst. Jeg tar utgangspunkt i kognitiv teori og praksisteori, og vil knytte risterens valg av språk og skrifttype til praksisene risterne opererer innenfor. Denne tilnærmingen kan gi en bedre forståelse av hvordan risterne samhandler både med andre ristere og det sosiale felleskapet gjennom innskriftene. Samtidig kan den også gi et større innblikk i hvorfor det aktuelle språket og skrifttypen ble valgt, og hvordan selvuttrykket påvirkes av språk og skrifttype.

\section{Begrepsavklaringer: skrift og innskrift, leser, formelle innskrifter og graffiti}

I denne artikkelen er "skrift", "innskrift", "leser", "formelle innskrifter" og "graffiti" sentrale begreper. "Skrift" anvender jeg om tekst i snever forstand: det som (i vår sammenheng) er skrevet med runer og bokstaver. På kirkeveggene finnes også bumerker, kors og andre kristne symboler og figurativ graffiti; dette er utenfor denne artikkelens område. I termen "innskrift" legger jeg all epigrafisk skrift, inkludert malt og vevet skrift. Innrisset eller -skåret skrift er likevel vanligst.

I en del tilfeller vil jeg også omtale leseren av innskriftene. Jeg vil gå ut fra at forsamlingen i sognekirkene er ei gruppe mennesker som relativt fast går i samme kirke, og at folk til en viss grad derfor kjente til navngitte personer i innskriftene. En del innskrifter henvender seg direkte eller indirekte til leseren, og jeg antar da at de retter seg både til presten og deltakere i forsamlingen i kirkerommet.

Graffiti er et begrep som brukes på mange ulike måter og i mange ulike kontekster. En grunnleggende definisjon er presentert av Lohmann 
(2020: 39), med referanse til Kraack og Lingens (2001: 9): grafiske tegn på en overflate som ikke primært er laget for dette formålet. Denne definisjonen gjør det lett å skille graffiti fra ikke-graffiti, men vil innlemme nesten all monumental epigrafisk skrift i graffitibegrepet. I denne sammenhengen trengs derfor en annen definisjon. Rozhdestvenskaja (2012: 254) og Blindheim (1985: 11) definerer graffiti etter et formelt kriterium, som henholdsvis skrift og tegninger risset inn med et skarpt objekt. Også Engtrø (2009: 101) setter opp formelle kriterier, og legger vekt på plassering, st $\varnothing$ rrelsen på skriften og dekorasjon som kriterier for å skille mellom graffiti og formelle innskrifter. Imidlertid er mye av det vi tenker på som graffiti i dag, både godt synlig og tegnet med tusj eller maling, og selv om den typiske runegraffitien er lite synlig og risset med en skarp gjenstand, finnes det unntak også i runematerialet (se for eksempel $\mathrm{N}$ 49-52 i Lom stavkirke, som er malt med tjære).

Ingen av de gjengitte definisjonene treffer helt det materialet jeg vil omtale, og jeg har derfor valgt å definere graffiti funksjonelt, som uautoriserte innskrifter; ${ }^{4}$ formelle innskrifter har jeg satt opp som en motsats, definert som innskrifter autorisert av en autoritet i kirka. Dette vil si at jeg regner dedikasjonsinnskrifter som formelle innskrifter; det samme gjelder andre innskrifter som forteller om hvem som bygde kirka, hvem som fikk den bygget osv. Slike innskrifter kan være autorisert av presten eller byggmesteren, som på byggetidspunktet også må regnes som en lokal autoritet. Det samme gjelder innskrifter som er en del av dekorasjonene i kirka, for eksempel på språkbånd i malerier i kirkene. ${ }^{5}$

Heller ikke denne definisjonen er uproblematisk, for mange innskrifter er i en gråsone, og det er sjelden mulig å vite sikkert om en innskrift var autorisert eller ikke. For eksempel har flere mulige dedikasjonsinnskrifter et graffitiaktig preg. Dette gjelder N $526^{6}$ (Pétrá mik "Peter eier meg") i Sakshaug gamle kirke, som er ristet med relativt grunne runer og uten noen utsmykning. N 470 (Lafranz á "Lafrans eier") i Nidarosdomen er ristet med store, grunne runer over restene av et alter på veggen av nordvestre tårn og er veldig ulik de lange dedikasjonsinnskriftene med

4. Liknende definisjoner blir brukt av Lovata og Olton 2015, Zilmer 2016 og Holmqvist 2019.

5. Disse innskriftene vil jeg omtale som dekorative innskrifter, selv om de gjerne kan ha flere formål enn det estetiske.

6. $\mathrm{N}+$ nummer $=$ innskrift fra Norge publisert i Norges innskrifter med de yngre runer (NIyR). 
bokstaver inne i Nidarosdomen. Risterinnskrifter, som N 146 (Kári Neriðssonr reist mik "Kåre Neridsson ristet meg", nå tapt) fra den tidligere Gåra kirke i B $\varnothing$ i Telemark, ble trolig ikke alltid ristet med prestens eksplisitte samtykke. Men mengden slike innskrifter i norske middelalderkirker tilsier at prestene må ha visst om dem. I enkelte tilfeller har også presten selv skrevet slike innskrifter på kirkeveggene, for eksempel på Talgje kirke på Finnøy i Rogaland (N 258): Pessar rúnar reist Eindriði prestr Jónsson, ok biðið fyrir mik "Disse runene ristet prest Eindride Jonsson, og be for meg”. Innskriften står over en fragmentarisk bevart seks til sju meter lang formell innskrift som vitner om reisingen av kirka (N 257). Runehøyden, $13-15 \mathrm{~cm}$ i den formelle innskriften mot 2,5-3,5 cm i Eindrides, viser at de to innskriftene ikke ble utformet som en enhet. Likevel tilsier nærheten mellom dem at de bør ses i sammenheng (jf. NIyR III: 272). Kan Eindrides innskrift regnes som en formell innskrift, all den tid den er skrevet av presten selv, og i samband med en annen formell innskrift? Innskriften til Eindride illustrerer mangelen på et skarpt skille mellom de formelle innskriftene og graffiti. De to termene bør heller forstås som ytterpunktene av et kontinuum, og dette kontinuumet er interessant når vi ser på forskjellen i bruken av runer og bokstaver. Mens runematerialet fordeler seg over hele kontinuumet, kan færre bokstavinnskrifter tydelig defineres som graffiti. Det finnes imidlertid eksempler på bokstavgraffiti, og stadig flere nye funn dukker opp. Disse innskriftene står i fokus i artikkelens andre hoveddel.

\section{Teoretisk tilnærming}

Jeg vil følge en forståelsesramme der kognitiv teori og praksisteori er satt sammen til et rammeverk for å analysere graffitiinnskrifter som selvuttrykk (se Holmqvist 2020a). Særlig vil jeg legge vekt på praksisteorien (jf. Reckwitz 2002a, 2002b; Schatzki 2001a, 2001b), der innskriftene forstås som resultat av en handling. Hver enkelthandling er igjen del av en st $\varnothing$ rre praksis. I denne praksisen inngår risteren som rister innskriften, verkt $\varnothing y e t$ risteren bruker for å riste og materialet risteren rister på, risterens kognisjon (både bevisste og ubevisste oppfatninger og ønsker) og de fysiske, kulturelle og sosiale omgivelsene. Alle disse aspektene er sentrale for å forstå innskriften, og dess flere aspekter vi har kjennskap til, dess mer kan vi si om innskriften i dag. 
I den nevnte modellen kan selvet forstås både som en kognitiv og sosial konstruksjon. Selvet er kognitivt fordi selvforståelsen skapes i hver enkelt risters kognisjon, men det er også sosialt fordi risterne som deltar $i$ en praksis, sammen skaper normer og forventninger til hvilke selv som kan uttrykkes i praksisen. Selvforståelsen jeg her sikter til, er den stadig skiftende oppfatningen vår om hvem vi er. Som Turner (2014: 77-78, 88) påpeker: Vi oppfatter selvet vårt som en enhetlig konstruksjon, men i realiteten er oppfatningen vår om hvem vi er, skiftende, og den tilpasser seg hele tiden til både vår egen strøm av tanker og omstendighetene rundt oss. Jeg ser praksiser som en viktig del av disse omstendighetene: Når vi går inn i en ny praksis, vil selvforståelsen vår ta utgangspunkt i praksisen og skapes i relasjon til denne.

Praksisteori og kognitiv teori er utviklet med utgangspunkt i vår egen samtid, og vi vil aldri få samme innblikk i en historisk praksis, eller i historiske personers kognisjon, som det er mulig å oppnå med samtidige studieobjekter. Disse teoriene gir likevel viktige innsikter i samspillet mellom individ og fellesskap som vi også kan dra nytte av i historiske studier. Her vil jeg særlig legge vekt på to faktorer, språk og skrifttype, som fortsatt er synlige i innskriftene, og jeg vil undersøke hva de kan fortelle om en annen, indirekte uttrykt, komponent i praksisen: risternes selvforståelse. Skrifttype og språk er knyttet til ulike skriftpraksiser, og det er ofte et skille mellom hva slags uttrykk som er ristet med folkespråk og latin, runer og bokstaver. For eksempel er formelle innskrifter særlig forbundet med latin og bokstaver, mens skriftlek på kirkeveggene særlig er forbundet med folkespråk og runer. Samtidig kan ristere velge å gå inn i ulike skriftpraksiser, og også blande ulike praksiser for eksempel ved å bruke et annet språk eller en annen skrifttype enn det som er forventet innenfor praksisen.

\section{Feltarbeid og materialavgrensning}

Jeg har gjennomført feltarbeid i Hopperstad og Borgund stavkirker henholdsvis 28. februar og 2. mars 2019 sammen med runologen Johan Bollaert. I tillegg har vi gjennomført feltarbeid i flere andre kirker for å få et bedre inntrykk av helheten i kirkematerialet og omfanget av bokstavinnskrifter i de norske kirkene. Jeg vil komme inn på funn fra disse kirkene 
der det er relevant å sammenlikne disse med innskrifter fra Borgund og Hopperstad.

Fokus for feltarbeidet var å få oversikt over innskriftene i kirkene og å lete etter nye innskrifter, særlig bokstavinnskrifter. Vi fant flere nye runeinnskrifter, og også enkelte bokstavinnskrifter som trolig kan dateres til middelalderen; disse vil bli presentert nedenfor. Samtidig kunne vi dokumentere store mengder bumerker som trolig er fra både før og etter reformasjonen, i tillegg til innskrifter med navn og årstall som fordeler seg utover hele den etterreformatoriske perioden. Her ligger vekten på skriftlige uttrykk med runer og bokstaver som trolig eller sikkert kan dateres til middelalderen, men også bumerker og etterreformatoriske innskrifter $b \varnothing r$ unders $\varnothing$ kes og dokumenteres videre.

Vi unders $\varnothing \mathrm{kte}$ alle tilgjengelige overflater inne og ute på kirkene, det vil si overflater i en høyde som er tilgjengelig for mennesker uten bruk av stige, stillas eller andre hjelpemidler. Graffiti finnes av og til også flere meter over bakken - eksempler på dette har vi fra Sakshaug (N 532) og Maeshowe (Or Barnes 1 og 2) - og vi kan ikke utelukke at det ville være mulig å finne flere slike innskrifter også i andre kirker. Alle innskriftene i Borgund og Hopperstad er likevel plassert i omtrentlig hodehøyde eller lavere.

Langt de fleste kirkeinnskriftene er funnet innvendig i kirkene; dette gjelder også for Hopperstad. Hovedgrunnen til dette er trolig at overflatene er bedre bevart innvendig enn utvendig. Veggene utendørs er utsatt for forvitring og slitasje, og tjære på stavkirkene og kalk på steinkirkene skjuler trolig mange innskrifter. Fra enkelte kirker - i hovedsak i stein - har vi likevel bevart innskrifter også utendørs. Flere stavkirker, deriblant Borgund, har dessuten en svalgang - en overdekket gang som går rundt hele utsiden av kirka. Taket bidrar til å beskytte veggene mot vær og vind, og i svalgangene finnes av og til innskrifter; i Borgund er for eksempel mer enn halvparten av innskriftene funnet i svalgangen. Også ombygginger av kirkene påvirker hvor man kan finne innskrifter og hvor mange innskrifter som er bevart. Mens Borgund regnes som ei av de best bevarte stavkirkene, er Hopperstad delvis rekonstruert på slutten av 18oo-tallet med Borgund som modell (se ill. 1 og 2 av Hopperstad og ill. 8 av Borgund). Svalgangen i Hopperstad er rekonstruert med moderne materialer, og derfor er det heller ikke mulig å finne innskrifter i denne svalgangen. Alle disse faktorene gjør at det er vanskelig å sammenlikne distribusjonen av innskrifter i de ulike kirkene. Å være i felt innebærer 
altså ikke bare å lete etter innskrifter, men også å vurdere overflater for å finne ut hvor innskrifter potensielt kan være bevart og synlige, hvor de kan være tapt, og hvor de kan ligge skjult bak lag av kalk, tjære eller maling. Ofte kan en gjøre slike vurderinger ved å se på gamle tegninger og sammenlikne fargenyanser og forvitring i ulike deler av kirka. De beste vurderingene ville likevel en konservator eller bygningshistoriker gjøre, og tematikken $b \phi r$ drøftes videre i en tverrfaglig studie.

Under feltarbeidet ble datering et presserende problem. For mens runene gradvis ble mindre brukt i Norge i seinmiddelalderen, har bokstavene vært $i$ bruk sammenhengende fra middelalderen til i dag. Fra slutten av 1500-tallet, og særlig utover 1600-tallet, ble det vanlig å datere graffitiinnskrifter med årstall, og takket være dette kan en i mange kirker spore en sammenhengende graffititradisjon fra 1600 -tallet til i dag. Imidlertid er mange graffitiinnskrifter udaterte, og noen av disse er trolig fra middelalderen. Derfor har jeg satt opp kriterier for å sile ut mulige middelalderinnskrifter med bokstaver:

- Innskriften må finnes på en bygningsdel/overflate som kan dateres til middelalderen.

- Innskriften må datere seg selv til middelalderen eller stå udatert.

- Bokstavformene i innskriften må være forenelige med bokstavformer som var i bruk i middelalderen.

I tillegg har jeg vurdert språket og meningsinnholdet i innskriftene, men uten å følge absolutte kriterier. Latin var i bruk lenge etter middelalderen, men jeg har inkludert udaterte latinske innskrifter som oppfyller kriteriene over. I 7.2 diskuterer jeg enkelte innskrifter på latin, og alle kan gis en plausibel datering til middelalderen. Også folkespråklige innskrifter kan være utfordrende, for det er ikke alltid mulig å skille norsk fra norrønt i en kort innskrift; mange navn har for eksempel hatt omtrent samme form fra norrøn tid til moderne norsk. Jeg har utelukket slike navn fordi det ville kreve uforholdsmessig mye tid å datere dem. Vi har lite grunnlag å basere en datering på, og videre forskning er nødvendig før en kan bruke udaterte navneinnskrifter i studier som denne. Bokstavinnskrifter uten språklig meningsinnhold er også utelatt; for disse gjelder samme vurdering som for navneinnskriftene. Jeg har likevel gjort unntak for store minuskelformer med innrisset omriss; disse skiller seg 
visuelt ut fra de andre bokstavinnskriftene, og vi har indikasjoner på at de er fra middelalderen (se diskusjonen om disse i 7.2).

Det finnes altså et bredt spekter av innskrifter på norske kirkevegger. Mange av disse kan stamme fra middelalderen, men bare i en brøkdel av tilfellene kan de dateres til middelalderen med sikkerhet. I artikkelens siste hoveddel vil jeg diskutere innskrifter med en usikker, men plausibel, datering til middelalderen og hva de forteller om seinmiddelalderske graffitipraksiser; først vil jeg likevel trekke fram runeinnskriftene i Hopperstad, som kan dateres sikkert til middelalderen, som utgangspunkt for å diskutere språk i graffitiinnskrifter.

\section{Språkbruk i kirkeinnskriftene: Hopperstad som eksempel}

Hopperstad stavkirke (se ill. 1) ligger i et slakt hellende terreng over tettstedet Vikøyri i Vik i Sogn, med utsikt ned mot Sognefjorden, og blir regnet som ei av de eldste norske stavkirkene. Tømmeret er nylig datert til 1131-32 med fotodendrometoden, og kirka er trolig bygget $i$ årene etter dette (Thun mfl. 2016: 111). På midten av 1300-tallet var Hopper-

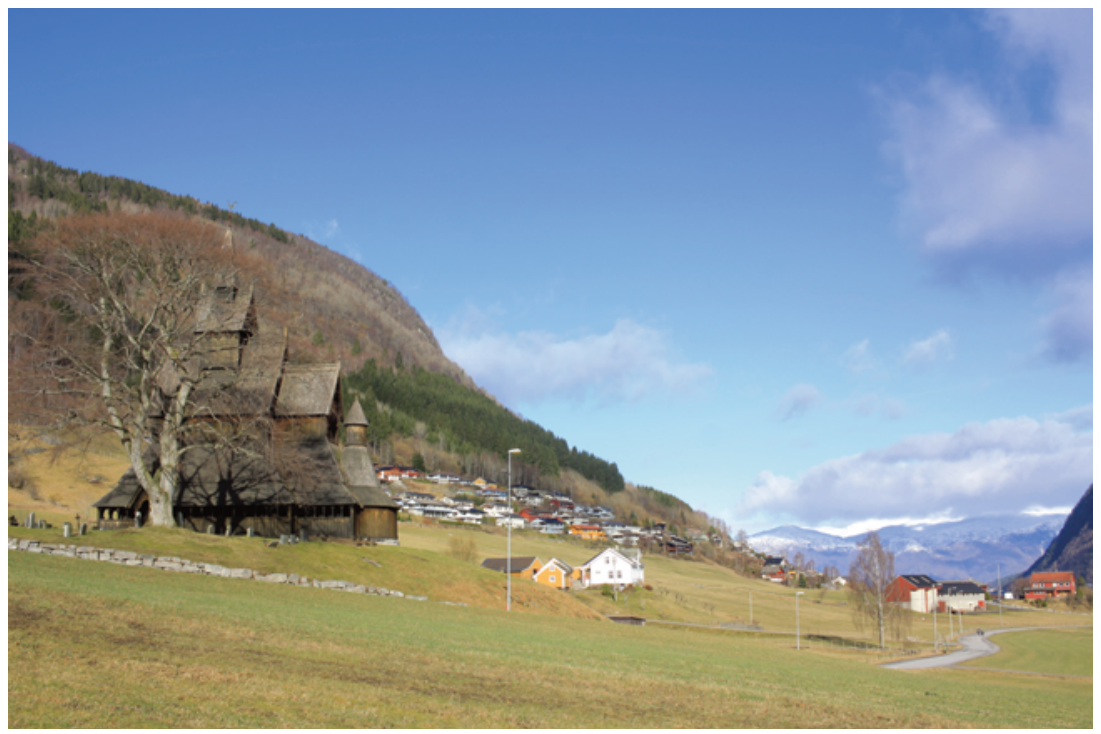

Illustrasjon 1. Hopperstad stavkirke sett sørfra, med utsikt mot Vikøyri og Sognefjorden. Foto: forfatteren. 


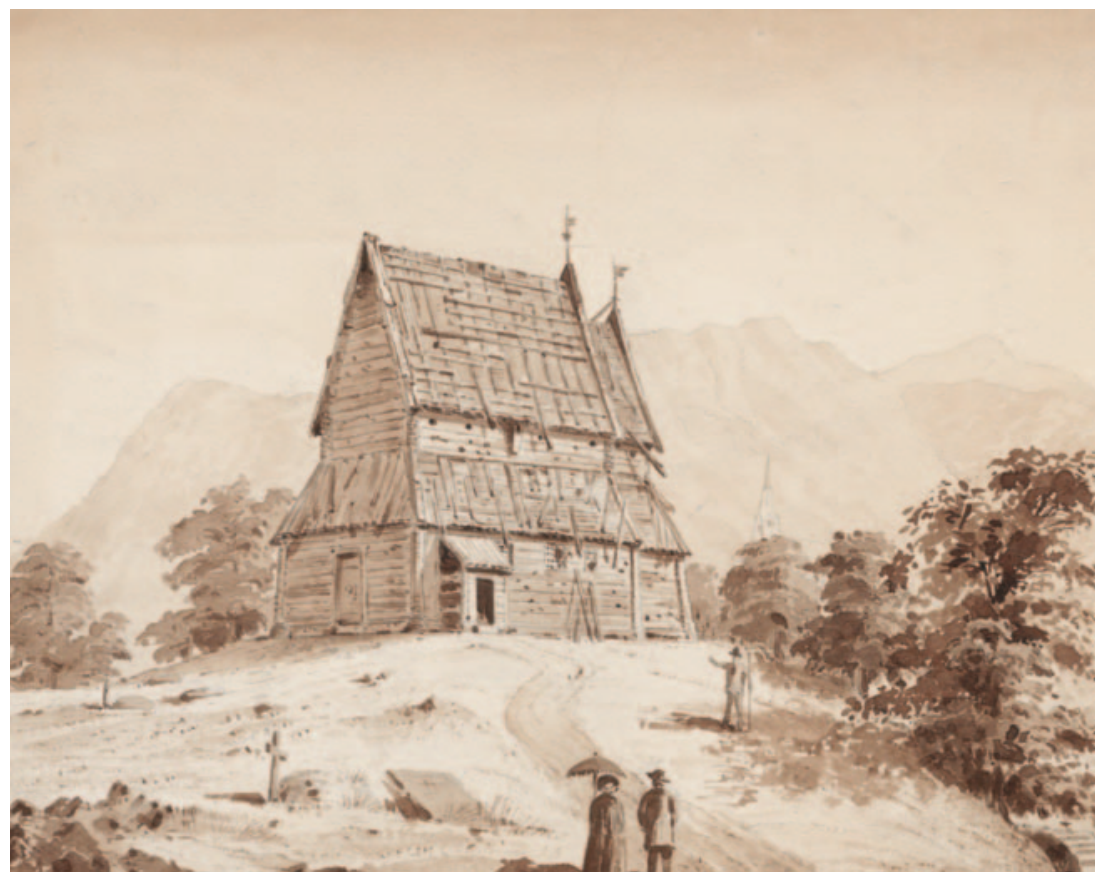

Illustrasjon 2. Hopperstad stavkirke slik den så ut etter at etterreformatoriske tilbygg var fjernet og for restaureringen. Akvarell av Peter Blix. Bildet er hentet fra Riksantikvarens tegningsarkiv.

stad ett av tre kirkesteder i Vik (Anker 2005: 128). Dagens kirkebygning er sterkt preget av restaureringen på slutten av 180o-tallet (se ill. 2 for en illustrasjon av kirka slik den så ut før restaureringen). Deler av kirkas indre og ytre utseende ble forandret i tillegg til at inventaret ble vasket grundig ned, noe som førte til at det meste av veggmalerier, både fra middelalderen og seinere, forsvant (ibid.: 136). Det er ikke utenkelig at også en del innskrifter gikk tapt i denne prosessen. Samtidig lå mange av runeinnskriftene under de etterreformatoriske veggmaleriene, og derfor kan vi også takke nedvaskingen for at vi kan se såpass mange runeinnskrifter i dag.

I alt er det funnet 22 runeinnskrifter på bygningskonstruksjonene i Hopperstad, alle inne i kirkerommet (se ill.3), og dette gjør Hopperstad til ei av kirkene i Norge der det er funnet flest runeinnskrifter. 20 av disse er dokumentert i NIyR bind 4; de to siste ble oppdaget av Johan Bollaert og undertegnede da vi unders $\varnothing$ kte kirka 28. februar 2019. De to 


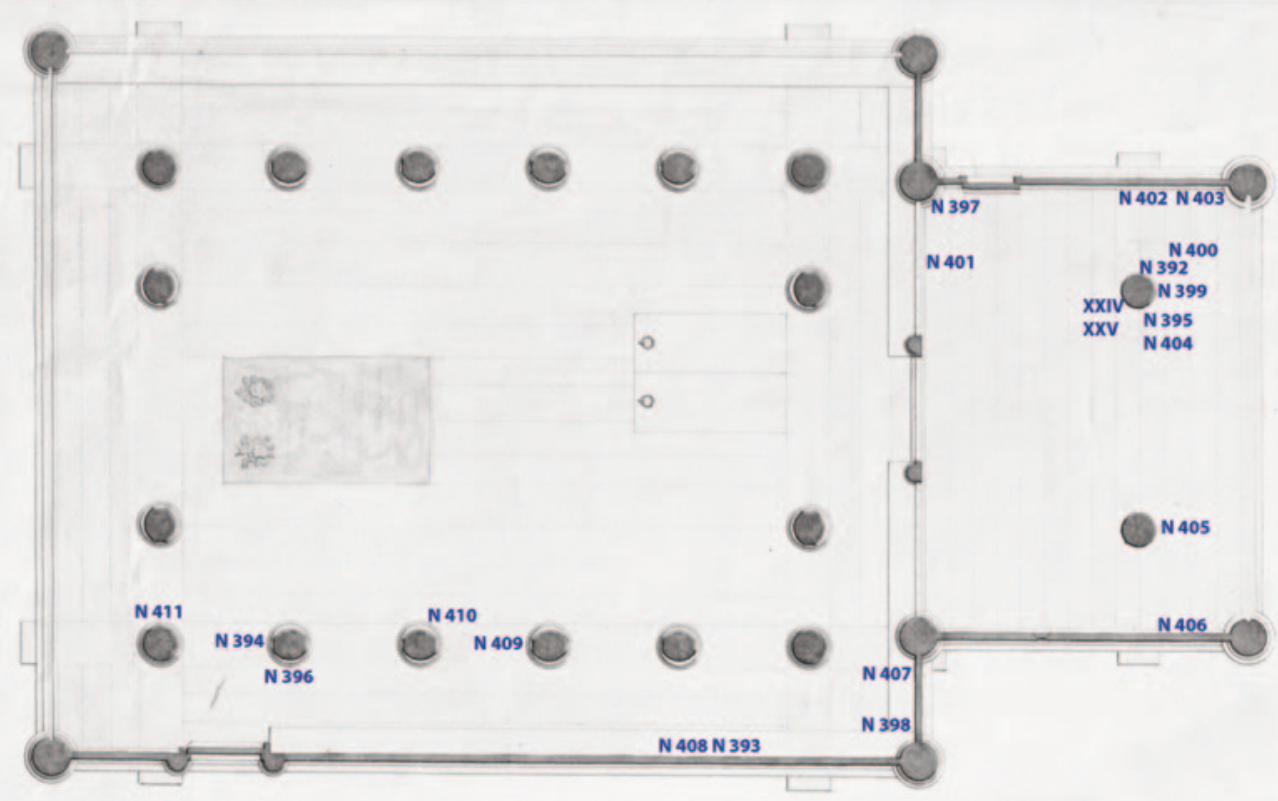

Illustrasjon 3. Grunnplan av Hopperstad stavkirke som viser hvor de 22 innskriftene er plassert $i$ kirkerommet. Plasseringen er omtrentlig. Plantegningen er laget av Georg Andreas Bull og er hentet fra Riksantikvarens tegningsarkiv. Bearbeidet av forfatteren.

nyfunne innskriftene har ikke fătt noe offisielt nummer fra Runearkivet i Oslo enda, og blir omtalt som henholdsvis Hopperstad XXIV7 og $\mathrm{XXV}^{8}$. Begge innskriftene ble funnet på sørvestre side av den nordre søyla i koret, ei søyle som også bærer flere andre runeinnskrifter. XXIV består av to binderuner, hver sammensatt av minst to runer; leseretningen er uklar (se ill. 4). Runene kan minne om venderuner som må leses $\mathrm{i}$ to retninger for å danne et ord, men det har ikke lyktes meg å finne noen klar mening i dem. Tentativt kan man lese runene $\mathbf{o}, \mathbf{m}, \mathbf{r}$ og kanskje $\mathbf{y}$ og $\mathbf{a}$, men leserekkefølgen er ukjent. ${ }^{9}$ Den ene kan minne om et

7. Innskriften står $162 \mathrm{~cm}$ over gulvet, og består av to runer som er omtrent $3 \mathrm{~cm}$ høye; innskriften er ca. 1,5 cm lang.

8. Innskriften står like nedenfor XXIV, $154 \mathrm{~cm}$ over gulvet, og runene er om lag $2 \mathrm{~cm}$ høye; innskriften er 3,5 cm lang.

9. Tegnforklaring: Feit skrifttype brukes til translitterering av minuskler og MAJUSKLER, og fonten Runlitt A for translitterering av runer. Kursiv angir nor- 


\section{Karen Langsholt HolmQvist}
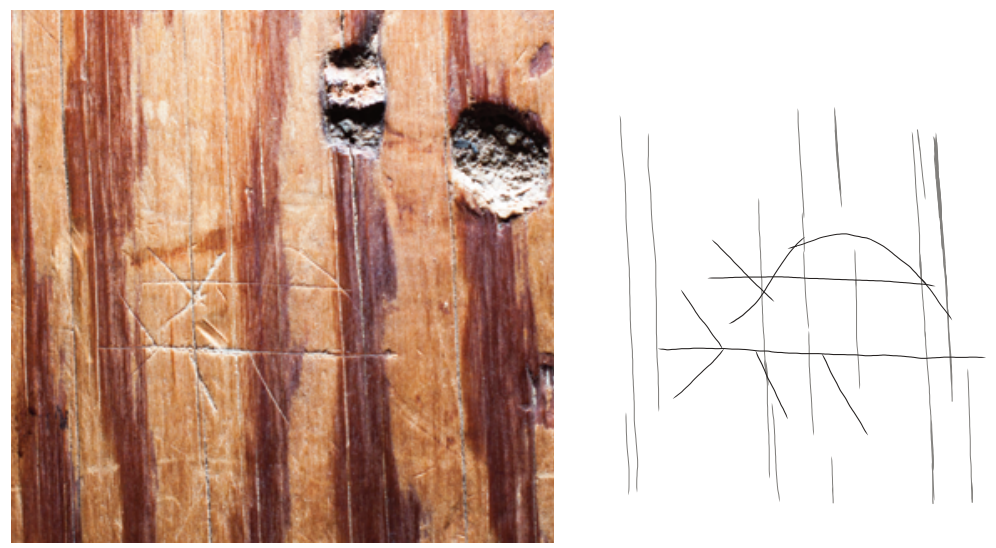

Illustrasjon 4. Hopperstad XXIV. Innskriften består av to binderuner. Foto: forfatteren.
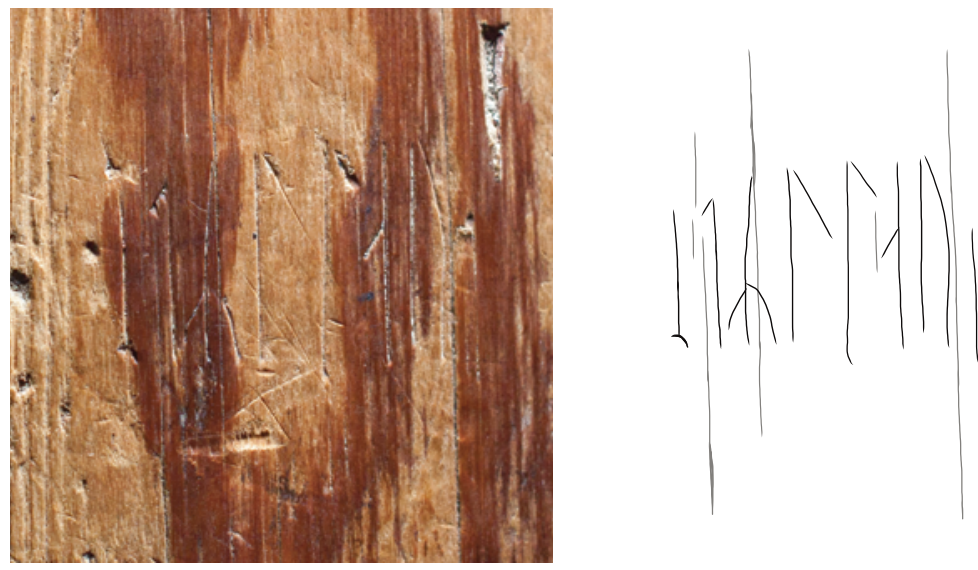

Illustrasjon 5. Hopperstad XXV. Innskriften gjengir navnet Styrlaug. Foto: forfatteren.

malisering; 'enkle anførselstegn' brukes for oversettelser. Underprikk angir en

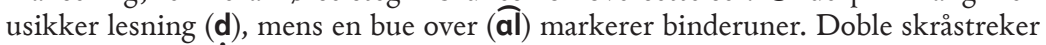
// brukes for visuelle brudd i innskriften, gjerne et linjeskift. Tre prikker brukes for å angi lakuner; en strek (-) angir en rune som kan telles, men ikke leses. Parentes brukes når tolkningen er usikker. Translitterering og normalisering er i hovedsak basert på Samnordisk runtextdatabas (med enkelte endringer, som buer for binderuner), men er kontrollert mot korpusutgavene og andre relevante publikasjoner. Der jeg har besøkt kirkene selv, er lesningen også kontrollert opp mot innskriften. Oversettelser er basert på korpusutgavene, med noen endringer. 
Maria-monogram; denne tolkningen vil jeg komme tilbake til. Hopperstad XXV består av åtte runer, styllau-, og kan leses som navnet Styrlaug (se ill. 5).

Innskriftene i Hopperstad er varierte og i stor grad representative for de norske kirkeinnskriftene fra middelalderen. Det er imidlertid uvanlig at én enkelt kirke har et så rikt spekter av innskrifter; bredden og antallet innskrifter man finner i Hopperstad, kan bare måle seg med Nidarosdomen og Lom og Borgund stavkirker. Distribusjonen av innskrifter innad i kirkerommet varierer også mye fra kirke til kirke, og analysen av denne kan derfor ikke generaliseres.

Både latinske og folkespråklige runeinnskrifter finnes i Hopperstad. Men der de latinske innskriftene gjerne er korte formularer, er flere av de norrøne innskriftene lengre personlige henvendelser på vegne av en gjerne navngitt person, og vendt mot leseren, Gud, jomfru Maria eller en helgen. De folkespråklige innskriftene er også mer varierte; mens de latinske innskriftene har et eksplisitt religiøst innhold, finner vi både trosytringer og skriftlek ristet på norrønt, i tillegg til navn. Videre vil jeg først diskutere de eksplisitt religiøse innskriftene, det vil si innskrifter med utdrag av bønner og liturgiske tekster samt innskrifter som på ulike vis henvender seg eksplisitt mot Gud, Maria, Jesus eller helgener, for eksempel gjennom bønner eller uttrykk for hengivenhet. Deretter vil jeg drøfte navne- og skriftleksinnskriftene.

\section{Folkespråk og latin: de eksplisitt religiøse innskriftene}

På den søndre veggen i skipet, fordelt over fire linjer, står den klart lengste innskriften i kirka, N 393:

+ nu $\cdot$ er $\cdot$ balm $\cdot$ sunụ $\cdot$ aft : an $/ /$ troten $\cdot$ hiabe $\cdot$ pæimanẹ $\cdot / /$ : er $\cdot$ pesar .

runar $\cdot$ ræist $\cdot$ sua $\cdot$ pæim $\cdot / /$ er $\cdot$ pær $\cdot \mathbf{r æ p r}+{ }^{10}$

Nú er palmsunnuaptann. Dróttinn hjalpi peim manni, er pessar rúnar reist, svá peim, er poer rceðr.

Nå er palmesøndagsaften [dagen før palmes $\varnothing$ ndag]. Herren hjelpe den mannen som ristet disse runene, og også den som tolker dem.

10. Lesningen er gjort av Johan Bollaert (pers. kom.) og skiller seg fra den i NIyR blant annet ved å ha flere skilletegn. 
Runene er ristet med tynne riss, men dekker en såpass stor flate at innskriften må ha vært relativt lett å oppdage selv i svak belysning. Innskriften er en lykkeønskning rettet både mot risteren selv og mot alle som kunne tyde den. Han tidfester sin egen innskrift til kvelden før palmesøndag, og kunsthistoriker ved NTNU Margrete Syrstad Andås (pers. kom.) foreslår at innskriften forteller om ei palmes $\varnothing$ ndagsvake i kirka. ${ }^{11}$ Påsken er kirkas viktigste høytid, og forbindes med både med synd, glede og botsritualer. Ved å fortelle at han var i kirka på palmesøndagsaften, viser risteren seg som en religiøs mann. Samtidig viser han fram sin egen fromhet når han ikke bare ber om Guds hjelp på vegne av seg selv, men også på vegne av leseren. Det at innskriften og ønsket om Guds hjelp er rettet utover til alle leserne, er sjeldent i de norske kirkeinnskriftene. ${ }^{12}$ Vanligvis retter risteren bønnen utelukkende mot seg selv eller andre navngitte enkeltpersoner. En slik innskrift finnes også i Hopperstad, i N 411:

\section{guphialpepæimermikræistinpatuahaukr}

Guð hjalpi peim, er mik reist, en pat var Haukr.

Måtte Gud hjelpe den som ristet meg, og det var Hauk.

Innskriften har en markert setningsstruktur der Gud settes først i setningen mens risterens navn, Hauk, kommer helt til slutt. ${ }^{13}$ Dette gir setningen en viss poetisk effekt, samtidig som risteren kan ha fors $\varnothing \mathrm{kt}$ å vise at han lever etter et fromhetsideal ved å sette Gud som første ledd i setningen. Begge de to siterte bønnene er dessuten formulert slik at det er

11. Dette er i så fall ikke den eneste innskriften som forteller om ei vake. $\mathrm{N} 473$ på Nidarosdomen er i dag sterkt skadet, men dokumenterer trolig at to personer vaket utenfor oktogonen under Olavsvakenatta.

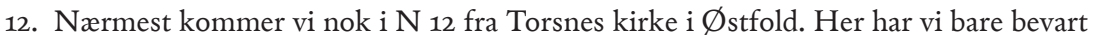
siste del av innskriften, som forteller at ' $[\mathrm{NN}$ gjorde $\mathrm{X}]$ til syndsforlatelse for Atle, for seg selv og for alle kristne folk.' Zilmer (2013: 143-144) trekker dessuten fram liknende eksempler på enkelte svenske runesteiner og gravsteiner. Utenfor kirkene finner vi innskriften N 169 i Vindlausloftet, der Vestein $\varnothing$ nsker det beste både for seg selv og leseren. Denne innskriften er imidlertid ikke formulert som en bønn, men snarere en lykkeønskning: Pessar rúnar reist Vésteinn. Heill sá en reist, ok svá baði sá en redr. "Disse runene ristet Vestein. Det beste for ham som ristet, og likeså for den som leser."

13. Strukturen er markert, men likevel ikke helt uvanlig. En liknende syntaktisk oppbygning finnes blant annet i innskrifter i Nidarosdomen ( $\mathrm{N} 478$ ) og i Lyngsjö kirke i Skåne (se Moltke 1985: 432). 
innskriften selv som snakker, mens risteren står i tredje person. Dette er nokså vanlig i runeinnskrifter. I én innskrift i Hopperstad, N 396 (ill. 6), lar likevel risteren sin egen stemme komme fram gjennom possessivet minn:

\section{kupminokhiælakmâria}

Guð minn ok (hin) helga María.

Min Gud og den hellige Maria.

Denne innskriften er ikke formulert som en bønn, men uttrykker inderlighet og hengivelse mot Gud og Maria. Possessivet forsterker nærheten mellom risteren og det guddommelige. I de to bønnene der risteren står i tredjeperson, forsvinner denne nærheten. Derimot oppnår risteren at bønnen framstår som mer allmenn, som om den ikke kommer fra risteren selv, men fra innskriften eller kirkeveggen og Guds hus.

De tre innskriftene er alle ristet på norrønt, og alle innskriftene befinner seg i skipet. Beveger vi oss inn i koret, er derimot en annen ristepraksis dominerende: Flere innskrifter er på latin, og de framstår mer
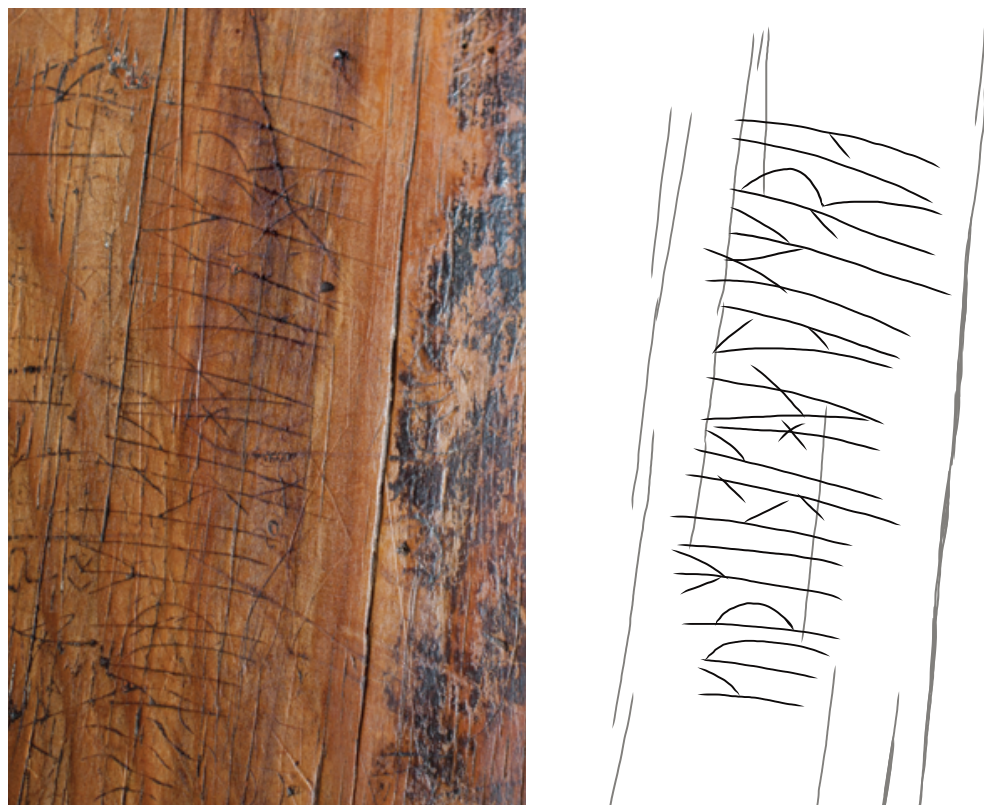

Illustrasjon 6. N396i Hopperstad stavkirke. Innskriften kan oversettes til "Min Gud og den hellige Maria”. Foto: forfatteren. 
som formularer enn som personlige henvendelser. Medregnet tre usikre innskrifter har vi seks innskrifter i koret som kan være på latin:

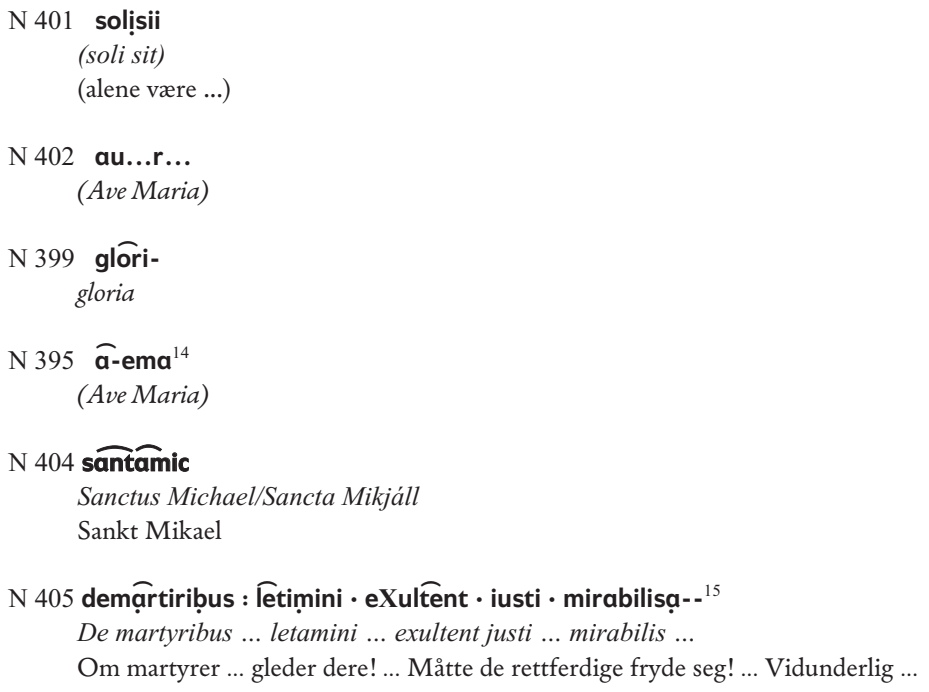

N 405 er den lengste innskriften på latin i Hopperstad, og den er også lang sammenliknet med graffitiinnskrifter på latin fra andre norske kirker. Innholdet i innskriften er enestående; Lilli Gjerløw (sitert i NIyR IV: 214-215) påpeker likheter med den liturgiske teksten In commune plurimorum martyrum, som finnes i Missale Nidrosiense. Ortografien ligger nær den man finner i manuskriptene og antyder at innskriftene er ristet av en latinkyndig person. Samtidig mangler den indre sammenhengen mellom frasene slik at innskriften framstår som tilfeldig sammensatt. Både denne innskriften og N 399 (gloria) kan minne om utrop man kan

14. Liest $\varnothing 1$ leser i NIyR rune 1 som en binderune $\widehat{\mathbf{a u}}$, men $\mathbf{u}$-buen sitter veldig lavt, og det er antydninger til en bue til over $\mathbf{u}$-buen. Denne kan være forenelig med en $\mathbf{r}$, men fordi den er svakere ristet enn resten av runene, kan den også være en feilristing. Jeg angir andre del av binderunen med strek for å vise at den ikke sikkert kan identifiseres; dermed blir også tolkningen av innskriften usikker.

15. Lesningen følger Knirk (1998: 498), og skiller seg på noen punkter fra lesningen i NIyR IV, som ble gjort av Liest $\varnothing 1$. I en rapport i Runearkivet (Liestøl 1954) gir Liest $\varnothing 1$ en oppdatert lesning som stemmer med den Knirk gjengir. Innskriften er svært fint ristet og delvis vanskelig å lese i dag, og da jeg unders $\varnothing$ kte innskriften i februar 2019, måtte jeg tidvis legge godviljen til for å se alle runene. Allerede i Liestøls notater gjengitt i NIyR (IV: 213) går det fram at innskriften delvis er vanskelig å lese. 
finne i veggmalerier i kirker, men det er likevel ingen klar kobling mellom innskriftene og malerier eller figurer som er synlige i dag. Det er mange innrissede figurer på veggene i kirka, men verken N 399 eller N 405 står i umiddelbar nærhet til disse. Figurrissene, som er dominert av forskjellige dyrefigurer, er ulike de typiske veggmaleriene med språkbånd, som gjerne gjengir for eksempel bibelhistorier. En kunne alternativt tenke seg at innskriftene har tilhørt veggmalerier som er tapt i dag, men det finnes ingen paralleller til dette fra andre kirker. Runene er også små og ikke spesielt dypt ristet. Visuelt ligger de dermed langt fra andre dekorative innskrifter fra norske kirker. Samtidig finnes ingen direkte sammenliknbare runeinnskrifter i andre norske kirker som kan underst $\varnothing$ tte eller svekke en slik tolkning.

Mer sannsynlig er det at innskriftene repeterer fraser fra et veggmaleri, for graffitiinnskriftene har ikke vært de eneste synlige tekstene i middelalderkirkene. Formelle innskrifter har funnes i mange kirker som del av veggmalerier eller annen kirkedekor, for eksempel på altertavler. ${ }^{16}$ I Hopperstad er det bevart et ciborium med takmalerier, som trolig en gang har stått over et Maria-alter (Gjesdahl 1969: 69; Kuhn 2020: 104), og takmaleriene har tilhørende malte bokstavinnskrifter på latin. Dateringen av maleriene og tekstene i ciboriet er problematisk, og det er ikke sikkert at akkurat disse innskriftene fantes i Hopperstad i middelalderen. ${ }^{17}$ Likevel illustrerer de hvordan formelle innskrifter og graffiti kan ha stått sammen i norske middelalderkirker. Innskriftene er med majuskler og gir enkle beskrivelser av motivene; for eksempel står ANGELVS : AVE : MARIA : ('Engelen: "Vær hilset, Maria"') sammen med bebudelsesscenen og NATIVITAS : DOMINI : ('Herrens fødsel') sammen med Jesu fødsel. Beskrivelsene utgjør ikke alltid fulle setninger; nativitas domini er for eksempel kun en nomenfrase. Slik kan tekstene i ciboriet minne om bruddstykkene fra $\mathrm{N}_{405}$, som også er sammensatt av løsrevne fraser.

16. Se for eksempel Sandquist Öberg (2017) for en omfattende studie av språkbåndene fra seinmiddelalderen i Uppland, Sverige. I Norge finnes det ingen tilsvarende filologiske studier av språkbåndene i veggmalerier fra middelalderen, men veggmalerier med skrift finnes blant annet i Slidredomen i Valdres, Tanum kirke i Bærum, Høyjord stavkirke i Andebu og i Nes kirke i Sauherad.

17. Takk til Linn Willetts Borgen, som påpekte dette for meg. For diskusjon om dateringen, se Gjesdahl (1969: 46-51), Stein \& Winness (2011: 6-7), Solem, Stein \& Berg (2017). 
Det har antakelig funnes et ciborium til i Hopperstad (Gjesdahl 1969: 81-82), og N 405 og N 399 kan ha gjentatt tekster fra dette ciboriet, for eksempel for å hjelpe lesere som ikke kunne lese bokstaver. Imidlertid ville en slik tolkning være langt mer troverdig dersom teksten også var oversatt til folkespråket og innskriften stod synlig og tilgjengelig i skipet. En mer nærliggende mulighet er derfor at risteren har gjentatt en bokstavinnskrift uten noen didaktisk baktanke, men kanskje heller som en $\phi$ velse i å riste runer på latin. Vi vet likevel lite om hva slags motiver og tekst som eventuelt har stått i det tapte ciboriet, slik at dette kun er en hypotetisk mulighet.

N 401 (solịsii) kan, som N 405, være et utdrag fra en liturgisk tekst; Olsen (NIyR IV: 213) foreslår at den er fra en variasjon av Soli Deo gloria. Samtidig er innskriften så fragmentarisk at den ikke kan tolkes sikkert. Det er mulig å tolke både denne innskriften og N 399 (Gloria) som lovprisninger, men i dag - flere hundre år etter at innskriften ble skrevet kan vi heller ikke utelukke at de har hatt en annen funksjon. Risterens opprinnelige intensjon er ukjent, vi mangler sammenliknbare innskrifter fra andre kirker og mye av konteksten - inkludert mulige veggmalerier og formelle innskrifter i kirkerommet - er borte i dag. Derfor forblir også betydningen til N 399, N 401 og N 405 usikker. Likevel vitner de om at ristepraksisene i kirkene var varierte - både i grad av latinkunnskap og innhold - og innskriftene minner om hvor mye kontekst som faktisk er tapt.

$\mathrm{N}$ 395, N 399, N 402 og N 404 består av korte fraser som kan ses som folkespråklige innlån; de latinske uttrykkene var så vanlige at en ikke trengte å kunne latin for å forstå dem. Mens N 405 må være ristet av en som behersket latin godt, eller eventuelt hadde et godt forelegg å skrive av, kan de andre latinske innskriftene være ristet av folk som bare hadde hørt latin i kirka. For disse var antakelig Ave Maria (N 395, N 402), gloria (N 399) og sancta (N 404) å anse som låneord fra latin. De gjenspeiler kontakt med latin, men ikke inngående kjennskap til språket. N 404 er en slags hybrid mellom latin og norrønt, der Sankt Mikael har fătt feminin tittel, med sankta heller enn sanktus. Zilmer (2013: 134) skriver om samme fenomen på Klemensker-steinen, $\mathrm{DR} 4 \mathrm{O}^{18}$ fra Bornholm i Danmark. Hun foreslår, med referanse til Jacobsen og Moltke i Danmarks runeindskrifter, at tittelen er et folkespråklig innlån. Foruten i Hop-

18. $\mathrm{DR}+$ nummer $=$ innskrift fra Danmark publisert i Danmarks Runeindskrifter. 
perstad og Klemensker opptrer også Mikael med tittelen sankta i fem andre innskrifter registrert i Samnordisk runtextdatabas, fire fra Danmark og én fra Gotland.

$\mathrm{N} 395$ og N 402 er fragmentariske, men tilsynelatende gjengir begge åpningsfrasen i bønnen Ave Maria. Mange runeinnskrifter i norske kirker er rettet mot Maria på ulike måter, og i Hopperstad finner vi de to nevnte innskriftene samt én annen usikker og én sikker Maria-referanse. ${ }^{19}$ Den sikre Maria-referansen (N 396) står på ei søyle s $\varnothing$ r i skipet: Guð minn ok(bin) helga María. Den usikre referansen er binderune-innskriften Hopperstad XXIV. Den $\varnothing$ vre av de to binderunene minner om en omdiskutert binderuneform som også finnes i stavkirkene i Lom (N 31), Øye (N 80) og Hurum (N 87), og som Olsen i NIyR bind 1 foreslår at er Maria-monogrammer. En kunne derfor se for seg at den ene binderunen i Hopperstad XXIV er en referanse til Maria, mens den andre for eksempel kan være initialene til risteren. Lesningen av denne innskriften er imidlertid svært usikker, og tolkningen må bli deretter. I tillegg er tolkningen av slike binderuner som Maria-monogrammer omstridt (se Bæksted 1944: 265 og Knirk 1998: 484, som vil ekskludere dem fra materialet, og Imer 2017: 112 og Skånberg 2003: 165, som regner liknende runeformer som Maria-referanser). ${ }^{20}$ Mulige eller sikre Mariareferanser er det mange av i kirkegraffitien fra middelalderen. Foruten runeinnskriftene finnes også en rekke bumerker med Maria-referanser (se Skånberg 2003).

Maria-kulten var utbredt både i norsk, skandinavisk og vest-europeisk middelalder (jf. Johansson og Bekker-Nielsen og Widding i KLNM XI 1966: kol. 352-367) og gir seg til kjenne i en rekke ulike uttrykk i kirkekunst og innskrifter (se Kjesrud 2015; 2018; Kleivane 2018; 2019; Sidselrud 2000). Kirkene hadde gjerne også et alter viet til Maria; dette kunne være det nordlige sidealteret eller høyalteret (Kuhn 2020). Ave Maria var velkjent og utbredt fra 110o-tallet, og på 1200-tallet ble den en av tre bønner, ved siden av Credo og Pater Noster, som alle skulle kunne. Ave Maria er den vanligste bønnen ristet med runer på kirkevegger, og de mange ulike Maria-referansene på norske kirkevegger er trolig uttrykk for den folkelige oppslutningen om Maria-kulten, som vokste

19. I tillegg finnes en sikker Maria-innskrift, $\mathrm{N} 412$ (mâria), på en lesepult i kirka, men denne faller utenfor materialavgrensningen i artikkelen.

20. Se også diskusjonen om Maria-monogrammer med bokstaver i avsnitt 7.2 nedenfor. 
fram i middelalderen. Samtidig er det betegnende både for innskriftene i Hopperstad og det norske kirkematerialet som helhet at Maria-innskriftene på latin i Hopperstad er et memorert formular, mens innskriften henvendt til Maria på norrønt er en mer personlig henvendelse som uttrykker risterens hengivenhet til Gud og Maria: Guð minn ok (bin) helga María. "Min Gud og den hellige Maria". Dette mønsteret, der latinske innskrifter er memorerte formularer mens folkespråklige innskrifter er friere formulert, er karakteristisk også for eksplisitt religiøse innskrifter med andre typer innhold, og gjenspeiler nok risternes språkkunnskaper. De som ristet graffiti i norske kirker, hadde i stor grad to alternativer for språk i innskriften: folkespråket eller et memorert latinsk formular. Få ristere var flytende i latin, og dermed var latin i stor grad ensbetydende med memorerte formularer.

De eksplisitt religiøse innskriftene i skipet og koret er så forskjellige at det er mest meningsfullt å snakke om to ulike ristepraksiser innad i kirkerommet: I koret velger risterne som vil uttrykke religiøs tilhørighet, upersonlige ytringer på latin, i skipet personlige ytringer på norrønt. Bruken av latin $i$ koret og folkespråk i skipet kan antyde at prester eller andre lærde ristet innskriftene i koret mens risterne i skipet var bes $\varnothing$ kende og deltakere i gudstjenester. Samtidig finner vi ikke det samme mønsteret i andre kirker. Valget av språk gjenspeiler også symbolikken knyttet til koret og skipet. Stavkirkeprekenen forteller at koret er et bilde på himinríkis dýr "himmelrikets herlighet", ${ }^{21}$ som speiles i valget av et språk som i Norge utelukkende ble assosiert med Kirka. Himmelriket speiles også $\mathrm{i}$ innholdet $\mathrm{i}$ innskriftene, som tidvis har karakter av lovprisning. Skipet representerer den jarðlega kristni “den jordiske kristenheten”, og dette ses $i$ at runeinnskriftene i skipet med religiøst innhold er personlige bønner fra jordiske kristne på folkespråket. Selv om de to gruppene av innskrifter skiller seg fra hverandre i form, plassering og språk, retter altså begge gruppene seg mot kirkebygget de er ristet på og aktivitetene som har foregått i kirkerommet.

I en gjennomgang av bønner ristet med runer påpeker Kristel Zilmer (2013: 166-167) at bønner på latin opptrer hyppigst på små objekter og runepinner, mens norrønt dominerer i bønner på offentlig synlige steder, som gravsteiner, runesteiner og kirkevegger, og hun foreslår at valget av

21. Dette og det påfølgende sitatet er normalisert fra AM 237 a fol., gjengitt i Kolsrud (1952: 89). Min oversettelse. 
språk i de offentlige innskriftene kan være motivert av et $\emptyset$ nske om å nå et større publikum. Dette er også sannsynlig i Hopperstad: Risterne som har $\varnothing$ nsket å uttrykke en form for personlig tilh ørighet til kirka eller som henvender seg direkte til leseren, rister på folkespråket i skipet, der alle hadde adgang. Samtidig finnes også en stor mengde runeinnskrifter og figurativ graffiti i mange kirkekor, noe som kan antyde at flere enn prestene har hatt adgang til koret i enkelte tilfeller.

Enkelte ristere kan også ha tatt hensyn til forestillingen om språkets kraft. Gustavson (1991: 556-557; 1994: 140) skriver, med henvisning til 1400-tallsteksten Siølinna thrøst, at bønner på latin ble sett på som mer effektive enn bønner på folkespråket. Samtidig framhever også Si๔linna thrøst viktigheten av at den som ber, forstår bønnen (Gustavson 1991: 556-557). Det kan virke som om risterne i Hopperstad har balansert mellom disse to hensynene. Noen ristet korte bønner på latin i håp om at de skulle ha mer kraft; andre henvendte seg mot det gudommelige med en personlig bønn på folkespråket. Valget av språk kan også påvirke den videre interaksjonen mellom leserne og innskriften. Flere innskrifter på folkespråket oppfordrer eksplisitt leseren til å be, og oppfordringen er mest virkningsfull dersom leseren skjønner innholdet. Ave Maria var likevel så kjent at en del lesere ville kjenne igjen bønnen selv om de ikke kunne latin, og kanskje også selv om de ikke var fullt ut skriftkyndige (jf. Kleivane 2018: 122).

I valget av språk kunne altså en rister både ta hensyn til forestillingen om mystikk og kraft knyttet til et språk han eller hun ikke fullt ut forstod, og den kraften en kunne oppnå gjennom egen forståelse og ved at en bønn på folkespråket kunne engasjere flere lesere. Hopperstad har eksempler på begge deler, men det at bønner på folkespråket dominerer, kan antyde at interaksjonen med lesere var en viktig del av graffitipraksisene på kirkevegger.

Innskriftene uttrykker ikke et enhetlig religiøst selv. Alle innskriftene som er gjengitt over, viser en klar bevissthet om at de står i ei kirke og relaterer seg til denne. Samtidig gjør de det på vidt forskjellige måter: gjennom bønner for risteren selv eller andre, uttrykk for hengivenhet til Gud og Maria, bruddstykker fra liturgien og standardiserte formularer på latin. Noen deler av denne praksisen forstår vi i stor grad. Det er for eksempel liten tvil om at risteren av N 411 ("Måtte Gud hjelpe den som ristet meg, og det var Hauk.") bruker kirkeveggen til å be en bønn for seg selv. Andre innskrifter tegner konturene av et enda bredere spekter 
av uttrykk som vi i dag ikke fullt ut forstår fordi både den fysiske og sosiale konteksten er en helt annen enn i middelalderen.

Innskriftene inngår i relaterte religiøse skriftpraksiser, og uttrykker både en sosial og religiøs identitet. Risterne vender seg til hverandre og det sosiale felleskapet gjennom direkte og indirekte henvendelser til leseren, og gjennom å følge de sosiale normene som ligger i skriftpraksisen. I Hopperstad inkluderer dette for eksempel å riste religiøse uttrykk på latin kun i koret, og eksplisitt religiøse uttrykk på folkespråket kun i skipet. De folkespråklige praksisene virker likevel friere, for som vi vil se nedenfor, finnes også navn og skriftlek på folkespråket i koret. Samtidig retter risterne seg også mot kirkebygget når de velger å riste på vegger og søyler, og gjennom det religiøse budskapet i innskriftene retter de seg mot det religiøse fellesskapet. Likevel er skriftuttrykkene de velger, varierte og forskjellige. Hver rister går inn i praksisen med sitt eget utgangspunkt; at innskriftene hører til samme praksis, betyr derfor ikke at innskriftene blir like.

\section{Andre folkespråklige innskrifter}

I tillegg til de eksplisitt religiøse innskriftene, som er skrevet både med latin og folkespråk, finnes også tre andre grupper av innskrifter i Hopperstad: navn, fuparker og diverse former for skriftlek. I Hopperstad er disse innskriftsgruppene rent folkespråklige; utenfor Hopperstad finner man en sjelden gang også lek på latin og latiniserte navn. Navneinnskrifter er relativt vanlige i kirkene, og i Hopperstad finnes to eller tre slike navn med norrøn språkform i koret, midt blant de latinske innskriftene. Det er ingen navn i skipet. En innskrift, N 400 hælhe, kan enten gjengi navnet Helge eller ha betydningen "hellig". Uten mer kontekst kan vi ikke vite hva risteren har tenkt, men navnets betydning gir en dobbelthet til innskriften som kanskje risteren selv også fant passende for en innskrift i koret.

Begge de to andre navneinnskriftene gjengir navnet Styrlaug ( $\mathrm{N}_{403}$ og Hopperstad XXV, se ill. 5), og er plassert nær hverandre på nordre korvegg og ei søyle nord i koret. Innskriftene har en spesiell s; denne er nesten like lang som de $\varnothing$ vrige runene, og avsluttes med en kort strek heller enn et punkt eller en sirkel. Dessuten har de samme stavemåte, der sekvensen $r$ staves II: styllaug/styllau-. ${ }^{22}$ Dermed er det sannsynlig 
at samme rister har ristet begge innskriftene. Dette er heller ikke den eneste kirka i Norge der samme navn opptrer flere ganger; i Byneset kirke opptrer navnet Arne to, eller kanskje tre, ganger i døråpningen i søndre korvegg, ${ }^{23}$ og i Værnes kirke opptrer navnet Bård tre ganger i et lite område på søndre korvegg (N 514, 517 og 518). I begge kirkene står navnene så tett og synlig at de må leses samlet som en gruppe: Enten er risteren den samme, eller så har flere ristere gjentatt samme navn. Det å riste ett navn flere ganger er altså en praksis kjent fra flere norske kirker, men utførelsen varierer, og det er usikkert om de gjentatte navnene har samme funksjon og betydning i de tre kirkene.

I Hopperstad har vi også to fuparker, begge i skipet på hver sin søyle i den søndre søyleraden. N 394 fuporkhai -- gjengir de to første ættene, men med litt vakling mot slutten. Dette kan leses som en indikasjon på at risteren ikke var spesielt st $\varnothing$ i runer, med mindre han eller hun endret runerekkefølgen med vilje for å skape flertydighet; liknende eksempler har vi for eksempel fra Maeshowe (Or Barnes 21, se Barnes 1994: 81; Holmqvist 2020b: 80) og Bryggen i Bergen (N B11b og N B87a, se Seim 1997: 184-85). N 410 fu gir bare de to første runene i fuparken, og dette kan være begynnelsen på andre ting enn en fupark, for eksempel et navn. Det er likevel vanlig å regne slike innskrifter som fuparker (jf. Knirk 1994: 175; Seim 1998: 8).

I tillegg kan fire innskrifter tolkes som ulike former for språklek:

\section{N 392 lokârfallokârsinilokârsponom}

Lokarr fal lokar sinn i lokarspónum.

Høvleren skjulte høvelen sin i høvelsponer

N $407 \quad$ synri
(syðri)
(søndre)
N 398 sunr
sonr/sudr
sønn/sør

er synlige. Vi kan dermed ikke være sikre på at siste rune har vært skrevet likt i de to innskriftene.

23. Disse innskriftene ble først oppdaget av Karin Fjellhammer Seim, og er dokumentert i en rapport til Runearkivet fra 16.9.2005. Jeg fikk kjennskap til innskriftene gjennom Dag $\varnothing$ yvind Engtr $\varnothing$ Solem, og unders $\varnothing$ kte dem sammen med Solem og Julian Cadamarteri 20.10.2018. Innskriftene er ikke publisert, og har heller ikke fătt et offisielt nummer fra runearkivet. 

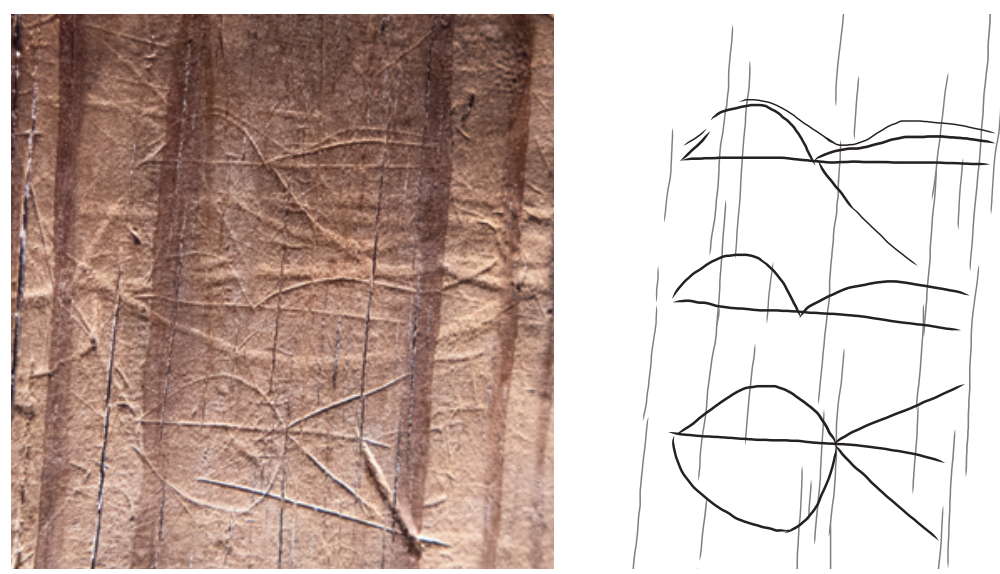

Illustrasjon 7. N 408 i Hopperstad stavkirke. Innskriften er trolig en oppfordring om å tolke runene. Foto: Johan Bollaert.

N 408 rrrâr

(Rád rétt rúnar.)

(Råd runene rett.)

Den første av disse innskriftene er risset inn i nordre søyle i koret, altså samme sted som de latinske innskriftene og ett/to av navnene, mens de tre andre er plassert i skipet. N 398 sunn og N 407 synri står nær hverandre på $\varnothing$ stveggen s $\varnothing \mathrm{r}$ for koret, på henholdsvis første og andre tile regnet fra den sørøstre hjørnestolpen, og N 408 rrrâr (ill. 7) står på den søndre veggen. $\mathrm{N} 408$ kan være en oppfordring om å tolke runene, der risteren har forvansket innskriften ved å bruke forkortelser, samtidig som han eller hun leker med speilvending i den første binderunen (jf. Nordby 2018: 64-65). Tilsvarende leker N 407 og N 398, som kan tolkes som henholdsvis "søndre" og "sør", med plassering og skrift, lydendringer og betydningsnyanser der de står på en vegg sør i kirkerommet. I N 392, om høvleren som skjulte høvelen sin i høvelsponene, skinner gleden over den språklige repetisjonen og det kryptiske meningsinnholdet klart og tydelig gjennom. Olsen (NIyR IV: 207) foreslår en tolkning der høvleren er en ordhøvler, høvelen er tunga og høvelsponene er tenner. En kunne nok også tenkt seg fram til andre, dypere lag av mening i innskriften, men innskriften, og Olsens tolkning av den, illustrerer hvordan lek med språk inviterer til mange og fantasifulle tolkninger, og dermed til videre lek. 
Flere av de folkespråklige innskriftene i kirker forholder seg ikke eksplisitt til kirkerommet som et religiøst rom, men noen av disse kan likevel tolkes i relasjon til kirkerommet. Det er vanlig å tolke innskrifter i kirker som bare består av et navn, samt innskrifter som består av et navn og en handling ("X ristet runer" eller liknende), som en markering av tilhørighet til kirka. ${ }^{24}$ Disse innskriftene kan leses som forkortede versjoner av innskrifter med en navngitt rister kombinert med en bønn, slik som Ámundi hann risti mik. Guð signi hann 'Amund han ristet meg. Gud velsigne ham' (N 506) fra Nidarosdomen (jf. Holmqvist 2018: 117). En slik tolkning kan også passe i de tilfellene der risteren har skrevet det samme navnet flere ganger; for hver gang navnet ristes, $\varnothing$ ker sjansen for at noen ser det og ber en bønn for den som har fått navnet sitt ristet på veggen. Imidlertid har risteren i Hopperstad valgt å bruke veldig små runer: De er bare om lag $2 \mathrm{~cm}$ høye og er særdeles vanskelige å oppdage uten godt lys. Å riste et navn flere ganger vil $\varnothing$ ke synligheten til navnet, men langt mer effektivt er det å riste større runer. Kanskje var det å knytte navnet til kirka i seg selv, og nærheten mellom de to innskriftene og ritualene som foregikk i koret, viktigere for risteren enn antallet lesere.

Også fupark-innskrifter opptrer av og til sammen med ulike former for kristent innhold (se Seim 1998: 237-242), og i noen sammenhenger også med mulig magisk innhold (ibid.: 258-260), så man kan se for seg at fuparken hadde magisk-religiøse konnotasjoner og av enkelte ble oppfattet som en slags bønn, eller i alle fall som et uttrykk passende for ei kirke. Gustavson (1991: 558-559) foreslår for eksempel at fuparkene representerer mindre skriftkyndige risteres $\varnothing$ nske om å feste skrift til kirkeveggen, og en tilsvarende tolkning kan også brukes på innskriftene som bare består av et navn.

En dristigere tolkning, også presentert av Gustavson (ibid.: 559), er at fuparken representerer summen av all kunnskap gjennom at man med den kan skape alle tenkelige ord. Slik ville den bli en folkespråklig parallell til alpha et omega, det vil si første og siste bokstav i det greske alfabetet. Disse blir brukt som både evighetssymboler og som en referanse til Jesu ord: «Jeg er Alfa og Omega, den første og den siste, begynnelsen og enden» (Åp 22:13). Denne tolkningen støttes av Skånberg (2003: 16o-

24. Se også Rozhdestvenskaja (2012: 255) for tilsvarende argumentasjon i en russisk kontekst. 
161), som foreslår at bumerker med f-runen kan ses som parallell til bumerker med majuskelen A, som han tolker som alpha etomega-referanser. Gustavsons tolkning er en god forklaring på hvordan fuparkinnskriftene relaterer seg til kirkerommet. Samtidig er fubarken så utbredt både i kirker og i andre kontekster fra middelalderen at dersom runeristere jevnt over hadde oppfattet den som en variant av alpha et omega, burde fuparken og alpha et omega av og til opptre sammen. Det finnes likevel ingen kjente eksempler på dette. I Samnordisk runtextdatabas er frasen Alpha et Omega registrert i til sammen seks innskrifter, inkludert en på kirkeveggen i Fortun stavkirke (N 306), som nå har brent ned. Denne stod ikke nær noen fupark-innskrift.

Samtidig er ens eget navn og fuparken noe av det første en fersk runerister ville lære seg å riste. I runepinnematerialet blir gjerne fuparker, ordspill og oppfordringer om å tolke runer forbundet med lese- og skriveopplæring i runer, og Nordby (2018: 238-239) argumenterer for at ulike former for språklek ble brukt som didaktisk instrument. Hans argument gjelder først og fremst kryptografiske runesystemer, som også finnes i flere kirker, men også andre typer ord- og språklek gir gode muligheter til å utforske og utvikle språk- og skriftferdigheter. Hopperstad er heller ikke den eneste kirka hvor slike innskrifter forekommer. I norske kirker finnes totalt 16 eller 17 mer eller mindre fullstendige fuparkinnskrifter, i tillegg til fem mulige rådeinnskrifter, hvorav to er helt sikre (N 575 Gol, N 352 Borgund). Det finnes også flere andre eksempler på skriftlek, blant annet flere kryptiske runeinnskrifter. Kan dette indikere at skriftopplæring var en vanlig aktivitet i norske kirker i middelalderen, og at ristepraksisene på kirkevegger overlapper med praksiser på blant annet runepinner fra urbane kontekster?

I flere kirker finnes innskrifter som etterlikner andre innskrifter i nærheten. Jeg har allerede nevnt Byneset og Værnes, der navnene Arne og Bård gjentas flere ganger. I motsetning til i Hopperstad er navnene her godt synlige. I Byneset kirke har dessuten navnet ulik utforming i hver innskrift. Her har en eller flere ristere prøvd seg fram med binderuner for å skape ulike visuelle realiseringer av navnet, og dette kan indikere at innskriftene ble til som et ledd i opplæring eller risteøvelser. I svalgangen i Borgund stavkirke står også innskriften N 364 tistilmistil ok-npiripipistil (kistill), mistill ok, binn priði, pistill '(liten kiste), misteltein, 
og, den tredje, tistel',25 med tre kortere variasjoner som står like i nærheten. Et tredje eksempel er bønneformularet Guð gati som er gjentatt tre ganger (N A85-87) av ulike ristere i Kaupanger stavkirke. Zilmer (2013: 139-140) ser innskriftene som tre ulike fors $\varnothing \mathrm{k}$ på å reprodusere den samme teksten. Dersom denne tolkningen stemmer, kan man anta at også disse innskriftene oppstod i en opplæringskontekst. Samtidig foreslår Lerche Nielsen (2019) at repeterende innskrifter i Bunge og Grötlingbo kyrka på Gotland bør ses i et helt annet lys. I disse kirkene gjentas blant annet horn-porn-korn-formelen, de sju første runene i fuparken, dvs. kalenderrunene, og syllabarier, og Lerche Nielsen (2019: 21) mener at innskriftene bør tolkes allegorisk:

Sammenfatningsvis mener jeg altså, at hornet, tornen og kornet allegorisk repræsenterer den gamle pagt, den ny pagt, samt det kristne budskab om indsigt i troen og håbet om sjælefrelse. $\mathrm{Og}$ alle tre ting er i den middelalderlige verdensopfattelse forenet $i$ kirkebygningen som fysisk manifestation.

Tolkningen kaster nytt lys over innskrifter man gjerne kobler til en opplæringskontekst. Den utelukker ikke direkte at innskriftene kan ha vært ristet som opplæring, men formlene som i så fall ble brukt, var neppe tilfeldig valgt. På samme måte kan tistel-mistel-kistel-formelen tolkes inn $\mathrm{i}$ en religiøs kontekst (jf. Schulte 2020), slik at også denne formelen er mer enn et repeterende formular.

Mange av de folkespråklige innskriftene kan altså tolkes inn i to ulike kontekster, en religiøs og en knyttet til skriftopplæring. Kanskje har innskriftene elementer av begge i seg. En bønn som er ristet som øvelse, kan fortsatt være nettopp en bønn. Enkelte ristere kan også ha valgt å $\emptyset$ ve på å riste sitt eget navn på kirkeveggen $\mathrm{i}$ håp om at andre kirkegjengere ville se navnet og be for dem. Samtidig har innskrifter som N 392, om høvleren som gjemte høvelen sin i høvelspon, mer preg av lek enn andakt. Vi må derfor åpne for at enkelte innskrifter er ren skriftlek uten noen st $\varnothing$ rre religiøs baktanke.

25. Innskriften følger en formel kjent fra flere runeinnskrifter (Nordby 2018: 104-109; Schulte 2020). Det tredje ordet er vanligvis kistill 'liten kiste, skrin'; her er det første ordet, tistil, foreslått normalisert til kistill i samsvar med Schultes (2020: 109) tolkning. 
I innskriftene der lek og $\varnothing$ velse er de mest framtredende aspektene, trår det religiøse selvet inn i bakgrunnen. Fram trer et skrivende selv som viser glede over språket og det å kunne uttrykke seg med skrift. Samtidig får flere innskrifter et sosialt preg fordi risterne i mange tilfeller hermer etter hverandre. Når språkglede og sosial samhandling blir hovedkomponenter, er det naturlig at risterne velger å riste på sitt eget morsmål og ikke latin. I hele kirkematerialet har vi bare to mer lekne innskrifter på latin, med runer i Lom stavkirke ( $\mathrm{N}_{43}$, hicuærsumscribo Hic versum scribo. 'Her skriver jeg et vers/ei linje.') og med bokstaver i Nidarosdomen (Syrett 9, ... - - VS // LAVREN // GELV(-) // AṆỤS // PEPRI Laurentius geluanus anus Petri 'Laurentius islending Peters anus'). ${ }^{26}$

Leken med språk og skrift følger antakelig risternes språk- og skriftkompetanse, og på samme måte som vi finner mer lek på folkespråk enn latin, finner vi også mer lek med runer enn med bokstaver i graffitimaterialet. Det er samtidig funnet langt flere runeinnskrifter enn bokstavinnskrifter i norske kirker. Dette er delvis fordi færre har lett etter bokstaver enn runer, men det er også funnet færre bokstavinnskrifter i de kirkene der man har lett spesielt etter dette. I neste del av artikkelen vil jeg diskutere innskriftene i Borgund stavkirke, der vi under feltarbeid gjorde flere nye funn av bokstavinnskrifter. Disse er en viktig kilde til kunnskap om ei innskriftsgruppe vi vet lite om.

\section{Valg av skrift i kirkene: bokstaver og runer i Borgund stavkirke}

Borgund stavkirke (se ill. 8) ligger i dalføret over Lærdal, på vei opp mot Filefjell, og langs en av de tidlige hovedferdselsårene fra $\emptyset$ st til vest over fjellet og pilegrimsleden mot Nidarosdomen. Dendrokronologiske unders $\varnothing$ kelser viser at $t \varnothing m m e r e t$ ble felt vinteren 118o-81, og kirka ble derfor antakelig bygd i årene etterpå (Thun m.fl. 2016: 109). I Borgund stavkirke har man funnet og dokumentert enkelte bokstavinnskrifter, og i tillegg 41 sikre eller mulige runeinnskrifter på kirkebygget og klokkestøpulen (se ill. 9). Ytterligere to trestykker med runeinnskrifter er fun-

26. Syrett + nummer viser til innskrifter fra Trondheim samlet og dokumentert av Syrett (2002). Tolkningen av innskriften er usikker, og baserer seg på at AṆUS leses to ganger. Se Syrett (2002: 158-162) for alternative tolkninger. 


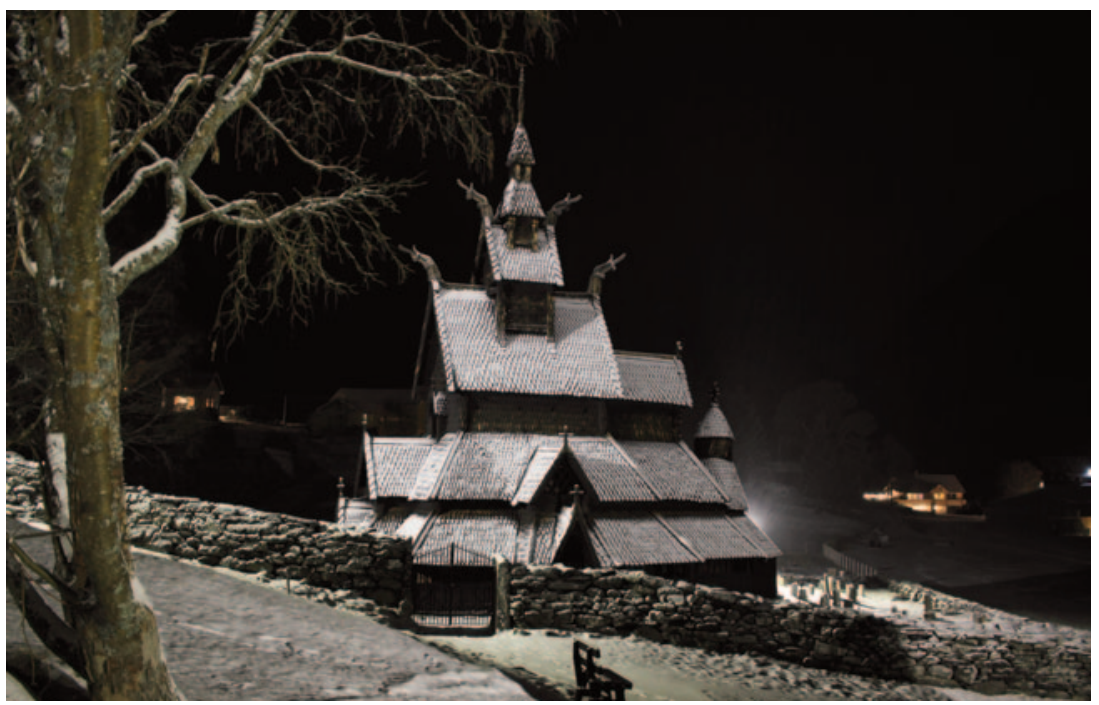

Illustrasjon 8. Borgund stavkirke sett fra sør. Mot nordøst fortsetter veien mot Filefjell og Østlandet; i motsatt retning slynger veien seg vestover ned mot Lardal og Sognefjorden. Foto: forfatteren.

net under gulvet i koret; disse er ikke graffiti og er derfor utelatt fra diskusjonen. Dette gjør Borgund til stavkirka i Norge med den desidert største samlingen av runeinnskrifter. Til sammenlikning har Nidarosdomen 42 sikre eller mulige runeinnskrifter; Lom stavkirke, som har nest flest registrerte innskrifter blant stavkirkene, står oppført med 26 innskrifter i Samnordisk runtextdatabas. 34 av runeinnskriftene i Borgund stavkirke er beskrevet i NIyR; fire innskrifter er beskrevet i Nytt om runer (Knirk 1989b, 1989a), og ytterligere to innskrifter er upubliserte, men dokumentert i Runearkivet ved KHM, UiO, og ble funnet av Annette Jones på 200o-tallet. Den siste innskriften ble oppdaget av Johan Bollaert og meg under feltarbeid. ${ }^{27}$ Noe av grunnen til at det er så mange innskrifter bevart akkurat i Borgund, kan være at dette er ei av de største og best bevarte stavkirkene i Norge. I tillegg kan pilegrimsleden og veien over fjellet ha ført mange skriftkyndige forbi kirka.

27. Innskriften, som vi har gitt nummeret Borgund XLIII, står i svalgangen på planken vest for portalen på søndre korvegg, og er sterkt forvitret og umulig å tolke. Den kan tentativt leses som ---u- : a : -har. Ytterligere informasjon finnes i en rapport i Runearkivet fra undertegnede og Bollaert datert til 31.12.2020. 


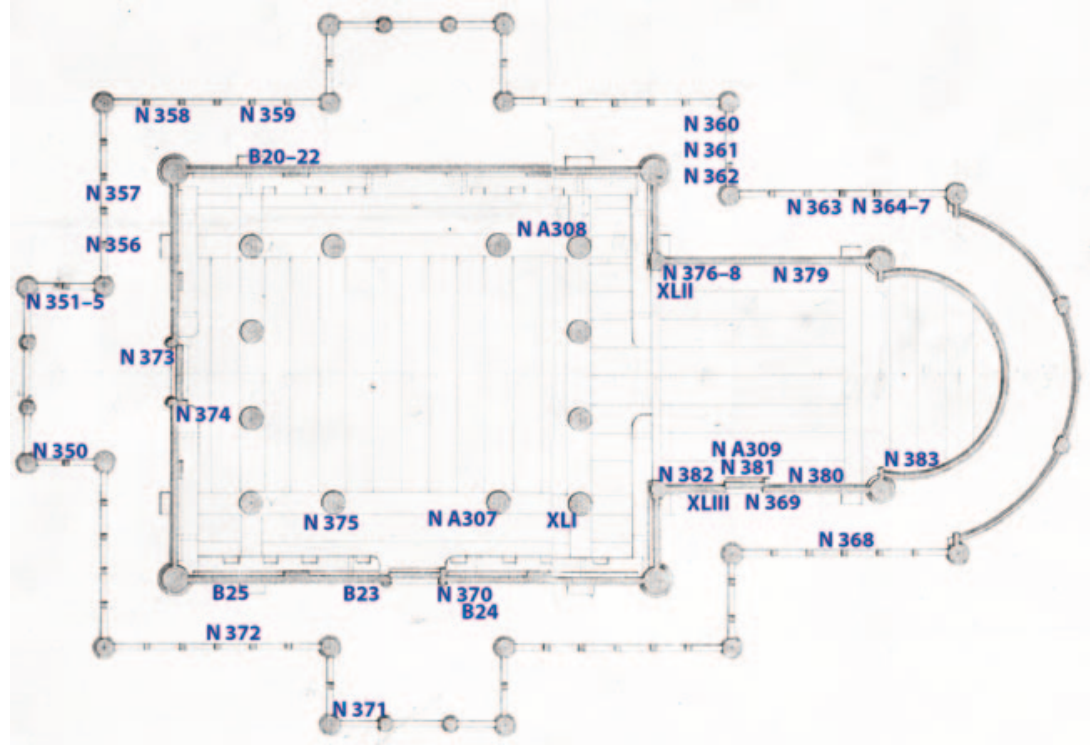

Illustrasjon 9. Grunnplan av Borgund stavkirke som viser hvor de 40 runeinnskriftene og seks minuskelinnskriftene er plassert. Plasseringen, serlig av minuskelinnskriftene (B20-25), er omtrentlig. Ytterligere én innskrift, N A297, ståri i klokkestøpulen. Plantegningen er laget av Georg Andreas Bull og er hentet fra Riksantikvarens tegningsarkiv. Bearbeidet av forfatteren.

\section{Runeinnskriftene i Borgund: Bokstavinnlån og knutruner}

Runeinnskriftene i Borgund og Hopperstad er nokså sammenliknbare i innhold, men det er funnet betydelig flere innskrifter i Borgund. Særlig to ting utmerker seg ved Borgund-innskriftene: en høy andel forskjellige språkleksinnskrifter - enkelte av disse er nevnt i diskusjonen om Hopperstad - og flere relativt lange folkespråklige religiøse ytringer. Selv om mange av innskriftene i Borgund er interessante og verdt å diskutere, vil jeg her bare omtale et lite utvalg. Disse innskriftene er spesielle fordi de låner inn bokstaven $\mathrm{K}$ eller tar i bruk sjeldne runeformer. Enkelte av innskriftene tematiserer også plasseringen av kirka. N 350, som står i svalgangen like ved vestportalen i kirka, forteller at pettasKirKiana Kirkiuuelle Petta er kirkjan á Kirkjuvelli 'Dette er kirka på Kirkevoll'. Kirkevoll er et gammelt gårdsnavn fra området, som også er kjent fra et diplom fra 1300-tallet (Rygh 1919: 76; DN III, nr. 371). Innskriftens 
plassering nær hovedinngangen gjør at innskriften kan tolkes som en slags velkomstinnskrift som forteller reisende hvor de er kommet.

En annen, liknende innskrift ( $\mathrm{N}_{357}$ ) finner vi også i svalgangen nord for vestportalen: kirkianâkirkiuuelliamik Kirkjan á Kirkjuvelli á mik 'Kirka på Kirkevoll eier meg'. Lesningen og tolkningen som er gjengitt her, er gjort av Knirk (1991). Innskriften er svakt risset og til dels svært vanskelig å lese; dette bemerker Rygh i notatene sine fra et bes $\varnothing \mathrm{k}$ i 1895 (faksimile i NIyR IV: 162), og Olsen, som studerte innskriften i 1935, understreker det samme (NIyR IV: 162). Olsen støtter seg på kilder som forteller at kirka er viet til Andreas, og foreslår, dels basert på Ryghs notater: Andrési (e)s kirkjan á Kirkjuvelli vígð 'Til Andreas er kirka på Kirkevollen viet'. Olsen finner også bokstaven $\mathrm{K}$ i innskriften, i motsetning til Knirk, som mener vi har runen $Y$. Da jeg unders $\varnothing$ kte innskriften $\mathrm{i}$ 2019, var den for utvisket til at jeg kunne vurdere tolkningen selvstendig. Det taler for Knirks lesning at han trolig har hatt bedre muligheter til å manipulere lysforholdene enn Olsen og særlig Rygh. Samtidig har antakelig innskriften blitt svakere med årene, slik at Olsen og Rygh i utgangspunktet har hatt bedre forutsetninger for å lese den. Det eneste som er sikkert, er at også denne innskriften refererer til kirkjan á Kirkjuvelli.

I N 350, og kanskje i N 357, er bokstaven $\mathrm{K}$ brukt sammen med runer. Bokstaven har samme form som runen $K \mathbf{p}$, men tolkningen av innskriftene viser at det er bokstaven og ikke runen som er brukt. Bokstaven $\mathbf{K}$ og runen $Y$ likner, og risteren kan ha tatt $\mathrm{i}$ bruk bokstaven ved en feil. Men på tross av at bokstav og rune er nokså like, er det ikke vanlig at runeristere forveksler dem. Mer sannsynlig er det at risteren valgte bokstaven bevisst som et estetisk element som framhever allitterasjonen i stedsnavnet: kirkjan á Kirkjuvelli. Bokstaven og runen er like nok i form til at lesere ikke ville være i tvil om tolkningen.

Samme tegn opptrer for $\mathbf{p}$ i tre innskrifter - N 351, N 355, N $368-$ og med usikker tolkning i ytterligere tre innskrifter: N 356, N 359 og Borgund $\mathrm{XLI}^{28}$. Siden tegnet opptrer både som rune og bokstav i Borgund stavkirke, vet vi ikke om det skal leses om K eller p, men N 356 og

28. Innskriften ble først oppdaget av Annette Jones, som beskrevet på bloggen hennes: https://knotrune.wordpress.com/why-knotrune/(Jones uten årstall). I 2010 ble den også unders $\varnothing \mathrm{kt}$ av deltakere på 7 th International Symposium on Runes and Runic Inscriptions. Jeg har gitt den nummeret XLI, for ut fra notater i Runearkivet ser den ut til å være den 41. innskriften som er funnet i Borgund. Innskriften har ikke fått noe A-nummer enda, og nummereringen er tentativ. 

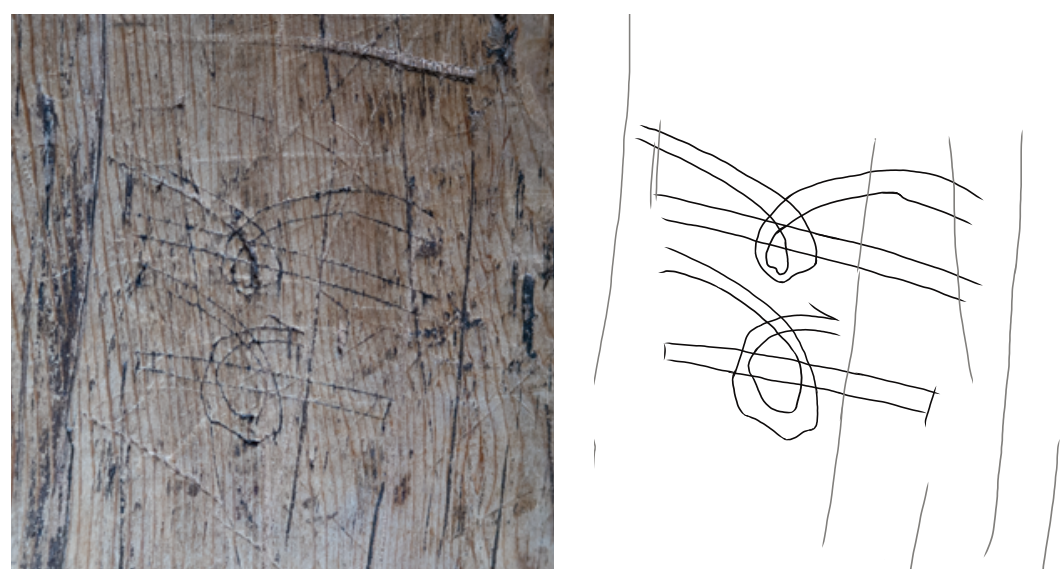

Illustrasjon 10. Borgund XLI. Innskriften består av to knutruner som er ristet med doble streker. Kvistene slynger seg om staven som knuter. Foto: Johan Bollaert.

Borgund XLI har usikre tolkninger som st $\varnothing t t e r$ at tegnet leses som bokstav. $\mathrm{N} 356$ består av fire tegn ( $K \nmid \quad B K \mathbf{p} / \mathbf{K} æ \mathbf{b p} / \mathbf{K})$, der de to siste er st $\varnothing$ rre enn de to første. Olsen foreslår at dette skal markere et skille i innskriften, og at den er en forkortelse for to tekster som hadde fast plass i liturgien: Kyrie eleison og Benedictus qui (venit in nomine Domini). Borgund XLI står på ei søyle sørøst i skipet og består av to tegn: YK kp/K. Innskriften kan tentativt ses som en forkortelse for Kirkian á Kirkjuvelli, og risteren kan ha valgt en rune og en bokstav for å markere at de to tegnene representerer hvert sitt ord. Denne tolkningen er likevel svært usikker.

Utformingen av tegnene i Borgund XLI er også bemerkelsesverdig: Linjene er dobbeltrissede, og kvistene slynger seg om staven som knuter (se ill. 10). Slike runer er kjent som knutruner, og er svært sjeldne; Imer (2017: 35-36) nevner seks andre tilfeller fra Grønland, Norge og Sverige. Knutruner er vanskelige å oppdage fordi de kan oppfattes som ornamenter istedenfor runer. Dette har vært tilfellet med en annen knutruneinnskrift på nordre korvegg i Borgund stavkirke, Borgund XLII ${ }^{29}$. Denne innskriften ble tegnet opp og fotografert av Blindheim (1985: pl. 8.2, nederst til venstre på planke 1), men Jones (uten årstall) var den første til å påpeke at dette faktisk var runer: râp. Nederst på $\mathbf{r}$-runen går staven og buen ned i to liljer. I denne innskriften møtes estetikk og lek. Innskriften

29. Også denne ble oppdaget av Annette Jones og er omtalt i samme bloggpost som Borgund XLI. Heller ikke denne har A-nummer, og nummereringen er tentativ. 
oppfordrer leseren til å tolke den (Rád!), og leseren må se forbi de estetiske elementene for å oppdage runene og tolke innskriften.

To av runeinnskriftene i Borgund leker altså med sjeldne skrifttyper og minst én innskrift tar i bruk bokstaven $\mathbf{K}$, kanskje som en form for ornament. Dersom bokstaven er et ornament, tyder dette på at flere av risterne i Borgund var svært runekyndige - noe også flere andre runeinnskrifter i stavkirka viser - og at de også hadde en viss kjennskap til bokstavene og trakk dette inn i runeristerpraksisene i Borgund. Risterne trekker inn bokstaver på svært bevisste måter, og viser slik fram et skriftkyndig selv. For disse risterne var trolig skriftkyndigheten en del av selvforståelsen - en kunnskap de, i motsetning til mange andre i samfunnet, hadde - og de lar dette skinne gjennom i innskriftene de rister. Ikke ved å knytte seg selv til innskriften ved å skrive hvem som ristet, men ved å bruke kunnskapen sin til å legge inn estetiske elementer og utfordringer til leseren i innskriftene.

\section{Minuskelinnskriftene i Borgund}

I Borgund finnes også flere bokstavinnskrifter med minuskler, som er risset inn i kirkeveggen med en skarp gjenstand $\left(\mathrm{B}_{20} \mathrm{O}-25\right)^{30}$. Disse ble oppdaget av Johan Bollaert og undertegnede under feltarbeid 2. mars 2019. Alle er funnet i svalgangen, på nordre og søndre skipsvegg. Bare én av disse innskriftene har leksikalsk innhold og faller inn under kriteriene presentert ovenfor; de resterende innskriftene består av enkeltminuskler, og er innlemmet på grunn av formlikheten med den leksikalske minuskelinnskriften. Ingen av innskriftene kan dateres sikkert til middelalderen, men de likner innskrifter fra danske kirker som kan dateres til omtrent det siste hundreåret før reformasjonen (jf. Plathe 2019), og en datering til slutten av middelalderen passer godt også med bokstavformene (jf. Bollaert under arbeid).

På sjette planke fra vest pånordre skipsvegg står den eneste av innskriftene med leksikalsk innhold (B2O; se Bollaert under arbeid for mer utfyllende beskrivelser). Den består av tre gotiske minuskler som er 3,5 cm høye: ihs. Dette er en vanlig forkortelse for Jesus basert på gresk sta-

30. $B+$ nummer viser til innskrifter fra middelalderens Bergen/Bjørgvin bisped $\varnothing m m e ~ i$ Johan Bollaerts katalog over bokstavinnskrifter. Tilsvarende er S+nummer fra Stavanger bisped $\varnothing \mathrm{mme}, \mathrm{H}+$ nummer fra Hamar bisped $\varnothing \mathrm{mme}, \mathrm{O}+$ nummer fra Oslo bisped $\varnothing \mathrm{mme}$ og $\mathrm{T}+$ nummer fra Trondheim/ Nidaros bisped $\varnothing \mathrm{mme}$. 

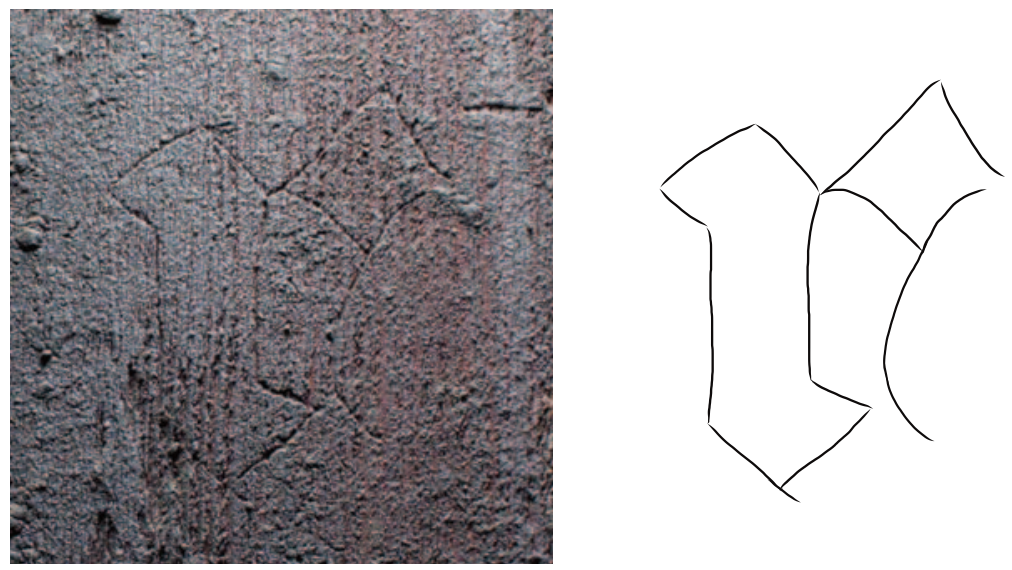

Illustrasjon 11. B23 i Borgund stavkirke. Innskriften består av en $6,5 \mathrm{~cm}$ bøy minuskel-r. Foto: forfatteren.

vemåte: $I H \Sigma O Y \Sigma$. Nedenfor denne står en $8 \mathrm{~cm}$ høy minuskelliknende form som kan se ut som en uferdig e (B21), og til venstre for denne igjen er det risset inn ytterligere to minuskelaktige figurer som er henholdsvis 6 og $9 \mathrm{~cm}$ høye (B22). Disse består av former som er kjent fra gotiske minuskler, deriblant brukne buer, men rissene er ikke ført sammen til fullstendige minimer eller minuskler. Dermed framstår figurene mer som uferdige minuskler eller $\emptyset$ velser på å risse minuskelformer. På søndre skipsvegg har vi også tre innskrifter med gotiske minuskler: På trettende planke fra vest finner vi en $6,5 \mathrm{~cm}$ høy $\mathbf{r}$ (B23, se ill. 11). På andre planke fra døra står to minuskler, til sammen $12 \mathrm{~cm}$ høye, som kan se ut som cs, der s-en er kort (B24). Lesningen av disse, og særlig av s-en, er usikker. På fjerde planke fra vest står en $14 \mathrm{~cm}$ høy a med åpen hals (B25). Minusklene har varierende st $\varnothing$ rrelse, men sammenliknet med runeinnskriftene i Borgund er alle minusklene store. Flertallet av runene i Borgund er til sammenlikning 3-4 cm høye; men de minste er så små som $1 \mathrm{~cm}$, og de største er 16. Og mens runene i Borgund i hovedsak er risset med enkle riss, er minusklene risset med doble riss, slik at risset følger minusklenes omriss. Dette gir assosiasjoner til formelle og dekorative epigrafiske minuskler på metall og i tekstilarbeid, og til en viss grad også til illuminerte manuskriptminuskler.

Vi kjenner få sammenliknbare bokstavinnskrifter fra norske kirker. Dette skyldes nok delvis at man sjelden har lett etter dem; runer har i 
mye større grad stått på dagsorden. Bollaert og jeg har gjennomført feltarbeid i til sammen nitten kirker, og i fem av disse finnes sammenliknbare funn: i Byneset kirke, Eidfjord gamle kirke, Kviteseid gamle kirke, $\mathrm{B} \varnothing$ gamle kirke og Nidarosdomen. ${ }^{31}$ Trolig kan man finne slike innskrifter i enda flere kirker dersom man leter godt og bredt nok.

Innskriften i Byneset kirke står i portalen i søndre korvegg. Her er det diverse innriss, inkludert runeinnskrifter, kors, bumerker og ulike geometriske former og symboler. Blant disse står to minimer som sammen kan danne en $\mathbf{n}$ eller $\mathbf{u}$, eller de kan være en figur som bruker former fra de gotiske minusklene.

I kalklaget i sørportalen til Eidfjord gamle kirke finnes flere innrissede minuskelinnskrifter ( $\left.\mathrm{S}_{4}-9\right)$; også disse står sammen med flere runeinnskrifter og andre innriss og figurer. Innskriftene ble først omtalt i korte trekk av Nordby (2003: 16) ${ }^{32}$ i en omtale av runeinnskriftene samme sted, og er grundigere beskrevet av Bollaert (under arbeid). Her finnes flere navn, i tillegg til at en latinsk frase, omnibus est nomen 'det er et navn for alt' går igjen flere steder. Bollaert (under arbeid) har vurdert bokstavformene og sett på opprinnelsen til frasen, og konkluderer med at innskriftene trolig er etterreformatoriske. I så fall er de sjeldne eksempler på etterreformatorisk kirkegraffiti som inneholder mer enn navn.

I Kviteseid gamle kirke fant vi spor etter seksten mulige eller sikre bokstavinnskrifter med varierte bokstavformer og av ulik karakter, skrevet med kull. ${ }^{33}$ Det meste er nær utvisket og vanskelig å lese i dag, men nok kan leses til at en kan si med sikkerhet at noen innskrifter er på latin. I tillegg finnes flere store, gotiske minuskler av samme karakter som dem vi fant i Borgund, og en innrisset form som minner om en minim ( $\left.\mathrm{H}_{2} \mathrm{O}\right)$.

31. Seint i arbeidet med denne artikkelen fikk jeg anledning til å unders $\varnothing$ ke også kirkene Siljan, Seljord og Høyjord sammen med Johan Bollaert, Susanne Kaun og Elisabeth Andersen, og vi fant tilsvarende minuskler også i Siljan (tre minimer, trolig en m) og Seljord (en $\mathbf{t}$ ). Disse vil bli beskrevet og publisert i en egen artikkel. Jeg har også sett bilder av liknende minuskler i enkelte andre kirker som jeg ikke vil omtale, da jeg ikke har kunnet undersøke dem selv. Disse funnene underbygger at det å riste minuskelinnskrifter er et fenomen med en viss utstrekning, og funnene vi har gjort, støtter fortsatt en datering til seinmiddelalderen. Tusen takk til Andersen og Kaun for informasjon og bilder.

32. Nordby har beskrevet funnene grundigere i notater i Runearkivet.

33. En stor takk til Susanne Kaun og Elisabeth Andersen som gjorde oss oppmerksomme på disse innskriftene, og som har diskutert dem med oss. 

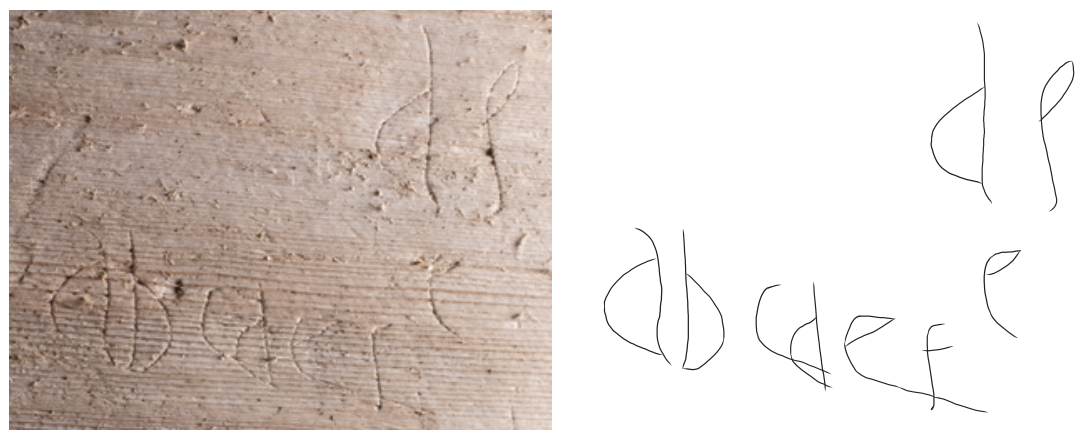

Illustrasjon 12. Oz2 i Bø gamle kirke. Innskriften er en alfabetinnskrift med minuskler. Foto: forfatteren.

Innskriftene i Kviteseid står sammen med mye figurativ graffiti, blant annet et reinsdyr og flere skip, og det kan se ut som om alt er del av samme dekorative uttrykk.

$\mathrm{B} \emptyset$ gamle kirke har to repositorier i koret, i søndre og nordre vegg, og i treverket på begge er det funnet flere innskrifter. De fleste av innskriftene er med runer, men på det søndre repositoriet, til høyre for åpningen, finnes også minuskler (O22; ill. 12): abcdef, e og dẹ. ${ }^{34}$ Minusklene er trukket opp med enkle linjer, og er - i motsetning til minusklene på Borgund stavkirke - på størrelse med runene i nærheten. een i $a b c$-innskriften avsluttes i et langt riss som også går gjennom f-en, og den neste e-en, som står over og til høyre for $\mathbf{f}$-en, kan være et fors $\varnothing \mathbf{k}$ på en ny, finere e. ḍẹ, som står over den siste e-en, har også en litt annen form enn d og e i abc-en. d-en har en mer kurvet stav (men ikke like kurvet som a), og e-en har en bøy som vender til venstre heller enn høyre. Det kan se ut til at risteren har lekt med bokstavformene eller $\varnothing \mathrm{vd}$ seg på å forme bokstavene med kniv i treverk. I tillegg til disse innrissede minusklene finnes det også antydninger til en lengre malt minuskelinnskrift tilsvarende dem som finnes i Kviteseid. Denne kan ikke leses i dag.

Innskriftene i Nidarosdomen er ikke direkte sammenliknbare med resten av det norske kirkekorpuset, for som erkebispesete og pilegrimsmål står Nidarosdomen i særstilling. Men også her er det relativt få graf-

34. Innskriftene er omtalt i Liestøl og Knirks notater i Runearkivet, og er publisert av Knirk (1986: 81). Han leser det siste settet med minuskler som ae. Bollaert (under arbeid) leser minusklene som de. Minusklene a og d er nokså like i $a b c$-innskriften, men jeg holder med Bollaert i at $\mathbf{d}$-en likner mest. 
fitiinnskrifter med bokstaver som sikkert kan tilskrives middelalderen. Holmqvist (2018) regner med femten innskrifter som med større eller mindre sannsynlighet kan dateres til middelalderen; av disse er tre formelle dedikasjonsinnskrifter. På tross av at Nidarosdomen har en spesiell status, kan en av innskriftene herfra, Syrett $5-7 / \mathrm{T}_{5}-7$, kaste lys over Borgund-minusklene. Innskriften har en dekorativ funksjon, og består av tre deler: SVAVE, EVAVS og VE. ${ }^{35}$ SVAVE og VE står plassert inne i små buer i utskjæringene фverst i kapitélen på to pilarer i triforiet, mens EVAVS står på utsiden av en hovedpilar. Suave (n. av suavis) er latin, og kan bety 's $\varnothing t$ '. Ordet er ofte brukt for å beskrive smaken, duften eller f $\varnothing$ lelsen av Gud eller det guddommelige (jf. Fulton 2006; Holmqvist 2018: 123). Her er det mest interessante ved innskriften hvordan SVAVE og VE er integrert i dekorasjonen på kapitélen. EVAVS, som speiler SVAVE, er ikke integrert på samme måte, og leker, på et vis, med de andre to innskriftene. Plasseringen, på utsiden av triforiet, antyder at de må ha blitt til før steinen kom på plass, eller at risteren enten hadde stillas eller uvanlig stor risikovilje. Innskriften er et eksempel på hvordan dekor, lek og lovprisning av Gud kan møtes i innskrifter fra middelalderen på måter vi ikke fullt ut forstår i dag.

Innskriftene fra Borgund er ikke helt unike i norsk sammenheng, men slike minuskelinnskrifter er lite kartlagt, og vi vet lite om hvor, når og hvorfor de ble ristet. Kanskje har de et dekorativt aspekt ved seg på samme måte som innskriftene i koret i Kviteseid, som står sammen med flere figurative motiver. I Borgund står minusklene alene, men det er også en innrisset figur i Kviteseid som kan se ut som en minim. Den står alene, og er ikke malt opp, men kan antyde at minuskler kanskje har vært både malt og ristet i Kviteseid. I danske kirker ble mange motiver risset inn f $\varnothing \mathrm{r}$ de ble malt opp (Plathe 2019: 31-34). Dersom det noen gang har funnes malte minuskler - eller andre malte motiver - i svalgangen i Borgund stavkirke, ville disse for lengst være tapt på grunn av forvitring.

De tre minusklene ihs er en forkortelse for Jesus, og det er mulig at også de andre minusklene er forkortelser og slik har vært tiltenkt en liknende betydning: $\mathbf{r}$ kan for eksempel stå for rex eller regina; $\mathbf{a}$ kan stå for ave. Bumerker med varianter av majuskelen $\mathrm{A}$ er de aller vanligste bumerkene i Skånbergs (2003) unders $\varnothing$ kelse av bumerker. I hans materiale

35. Syrett (2002) ser de tre delene som ulike innskrifter, og nummererer dem som 5-7 i korpusutgaven sin over bokstavinnskrifter fra Trondheim. 
utgjør disse 3274 registreringer av totalt 27595 (2003: 70-71). Dette indikerer at mange har tillagt A-en en spesiell betydning. Skånberg (ibid.: 159) knytter A-bumerkene til Jesu ord $\mathrm{i}$ Johannes' åpenbaring 22:13: "Jeg er Alfa og Omega, den første og den siste, begynnelsen og enden.” Kanskje kan a være en tilsvarende referanse. Det finnes også mange vanlige latinske ord fra liturgien som cs potensielt kan kobles til, for eksempel Christus, crux, spiritus, sanctus eller communio sanctorum. Samtidig er det umulig å slå fast hvilke ord risteren eventuelt har tenkt at minusklene står for.

I enkelte danske kirker finnes malte monogrammer med gotiske minuskler (Plathe 2019: 228). Det finnes flere ihs og Maria-monogrammer bestående av en gotisk minuskel-r med en buet sidestav ut fra staven på hver side som kan leses som M. I noen tilfeller har monogrammet også tverrstreker som indikerer at sidestavene skal leses samlet som $\mathbf{M}$ og enkeltvis som to A-er. I andre tilfeller mangler tverrstrekene, og da kan monogrammet eventuelt leses som en forkortelse for Maria regina. I tillegg finnes gotiske $\mathbf{p}$-er, $\mathbf{r}$-er og $\mathbf{m}$-er. Minusklene $\mathbf{r}$ og $\mathbf{m}$ er i noen tilfeller kronet, og da er det nærliggende å tenke på rex og Maria, himmeldronningen. Kronet $\mathbf{m}$ og $\mathbf{M}$ var vanlig som Maria-monogram i Sverige, men i Norge var det vanligste Maria-monogrammet en A med knekk på tverrstreken som dermed kan leses som en A og en $\mathbf{M}$ (Trætteberg i KLNM XI 1978: kol. 682); dette monogrammet finnes dessuten blant bumerker og kors på mange norske kirker. Kronet $\mathbf{m}$ finnes imidlertid også $\mathrm{i}$ Norge, blant annet på ei sølvskje fra Stjørdal (se Dybdahl 2002: 36 for et bilde av gjenstanden). Det at nettopp $\mathbf{m}$, en minuskel bestående av tre gjentakende minimer, har gått igjen som en enkeltstående minuskel, kan ha gitt enkelte ikke-skriftkyndige inntrykk av at selve minim-formen har betydning. Dette kan være opphavet til minimene som er innrisset i flere kirkevegger.

En del av de danske kirkene som har monogrammer, har flere av dem, og monogrammene kan stå så å si alene som utsmykning i hvelvene. Derfor mener Plathe (2019) at monogrammene har vært en sentral del av utsmykningen her. I Stege kirke står Maria- og Jesusmonogrammer, samt navnene Johannes og Anna, to steder sammen med bønner skrevet med minuskler: beder goth for (ibid.: fig. 72, s. 85) og beder for os (ibid.: fig. 73, s. 86). Innskriftene er fra 1494, og ble malt opp i hvelvene da de var nybygde, men ble oppmalt i 1892, slik at vi ikke vet sikkert hvordan originalene har sett ut. Mye skiller minusklene i Borgund fra innskriftene 
i Kviteseid og ikke minst Stege kirke, og vi kan ikke uten videre anta at minusklene i Borgund har hatt samme synlighet eller funksjon. Likevel er det interessant å se til andre kirker for å unders $\varnothing$ ke hvordan liknende innskrifter står plassert der, fordi disse viser tydelig at minuskelformer kan ha en symbolsk funksjon og stå som sentrale elementer i kirkeutsmykningen.

Innskriftene kan også ses i sammenheng med bruk av minuskler i andre kontekster. De gotiske minusklene har samme form som bokstavene i formelle epigrafiske innskrifter på gravsteiner og altertavler, tekstiler og kalkmalerier. Disse innskriftene gjenga ofte bønner eller utdrag fra Bibelen, gjerne sammen med figurative religiøse motiver. Gjennom denne formlikheten blir minusklene en påminnelse om bokstavenes autoritet, hellige skrifter og Bibelens ord. Slik trenger ikke hver enkelt bokstav å stå for et spesifikt ord, men kan bære med seg assosiasjoner til Bibelens skrift og kraften i denne.

Borgund-minusklene kan også ha vært ristet som $\varnothing$ velse, på samme måte som man trolig har brukt kirkeveggene til å $\varnothing \mathrm{ve}$ på å riste runer. Også minimene vi har funnet på Byneset og i Kviteseid, kan være фvelser på å tegne opp grunnformen for minusklene. I B $\varnothing$ har vi dessuten de første seks bokstavene i alfabetet sammen med et par variasjoner av enkelte av bokstavene. Disse danner en parallell til de mange fupark-innskriftene med runer, ikke minst fordi det var vanlig å riste bare de første seks runene. Imidlertid er det ikke usannsynlig at B $\varnothing$-minusklene er samtidige med runeinnskriftene i nærheten og dermed antakelig betydelig eldre enn Borgund-minusklene. ${ }^{36} \mathrm{Vi}$ har indikasjoner på at ristere har $\emptyset v d$ på bokstavformer også i Borgund: Ved siden av og litt nedenfor ihs finnes flere minuskelaktige former som ikke danner ferdige bokstaver, men som imiterer noen av minuskelformene. Disse kan være $\varnothing$ velse eller en etterlikning av bokstaver ristet av en ikke-skriftkyndig rister. Eksemplene danner paralleller til runematerialet, der vi tilsynelatende har skrift$\emptyset$ velser og etterlikning på kirkeveggene. Samtidig er minuskel- og miniminnskriftene i Kviteseid, Byneset og Borgund mest trolig fra slutten av middelalderen $-\mathrm{i}$ alle fall dersom innskriftene har en sammenheng

36. Antakelsen om at $\mathrm{B} \varnothing$-minusklene er eldre enn Borgund-minusklene, underst $\varnothing$ ttes også av at $\mathrm{B} \emptyset$-minusklene i form minner mye om minusklene som er funnet på mange danske blyamuletter, og som dateres til 1200-1300-tallet. Se for eksempel Imer \& Olesen (2018). Takk til fagfellen som påpekte dette. 
med minusklene i danske kirker. I så fall er de sannsynligvis minst hundre år yngre enn de yngste runeinnskriftene i kirkene, og likhetene kan være rene tilfeldigheter.

Dekorasjon, symboler eller $\emptyset$ velse - det finnes flere mulig tolkninger av minuskelinnskriftene, og kanskje kan de ha hatt flere funksjoner på samme tid. At en rister $\varnothing$ ver seg på å skrive, betyr ikke at det han eller hun skriver, ikke har mening og estetikk. Og det som for en rister har vært en skriftøvelse, kan for en seinere leser ha dypere lag av mening. Avhengig av hvilken tolkning man lener seg mot, kan også ulike selv tre fram. Felles for dem er imidlertid assosiasjonene minusklene bærer til den st $\varnothing$ rre skriftlige og litterære tradisjonen. I valget av form - store minuskler lik dem man finner i formelle innskrifter - knytter risteren seg opp til denne og uttrykker en tilhørighet til, eller fascinasjon for, den lærde og litterære tradisjonen.

Minusklene på Borgund stavkirke antyder konturene av et fenomen vi vil trenge mer empiri og forskning for å forstå. Det vi har av empiri, viser at også bokstaver ble brukt i graffiti i kirkene, og de blir, på samme måte som runene, brukt til et spekter av ulike uttrykk. De store, gotiske minusklene er på samme tid den uformelle graffititypen vi vet minst om og som tilsynelatende opptrer oftest og med størst geografisk spredning: i Borgund i Sogn, på Byneset i Sør-Trøndelag og i Kviteseid i Telemark. Vi har foreløpig for lite empiri til å si hvor utbredt bokstavgraffiti fra middelalderen er, men den som leter, vil antakelig finne mer. Samtidig har trolig mye gått tapt.

\section{Oppsummerende diskusjon}

I kirkene finnes ei rekke varierte skriftpraksiser med tilhørende selvuttrykk, særlig knyttet til runene. Runematerialet viser et spekter av religiøse ytringer på latin og folkespråk, sosial samhandling og trolig skriftlek og - $\varnothing$ velser. Enkelte ristere briljerer nærmest med runekunsten sin. Bokstavgraffiti er sjeldnere; tilsynelatende består materialet særlig av religiøse uttrykk, men også dekorasjon og kanskje skriftøvelser. Samtidig forsvinner ei rekke selvuttrykk mer eller mindre fra kirkene når runeskriften går ut av bruk. Noen går trolig over til andre former som ikke lenger er synlige i dag, eller som vi trenger mer kunnskap om for å forstå. Dette gjelder for eksempel ristepraksisene der individet knytter seg opp 
til kirka og menigheten gjennom lengre, personlig formulerte bønner. Kanskje finnes liknende uttrykk i symboler, initialer og bumerker, men disse har vi fortsatt lite kunnskap om. Andre selvuttrykk faller trolig bort permanent, slik som praksisen i Hopperstad der skriftlek og runekunst i seg selv er målet. Disse skriftpraksisene er så tett knyttet til selve runeskriften at de blir umulige å føre videre når kunnskapen om runer faller bort.

Dersom dateringen av minusklene i Borgund til de om lag siste hundre årene av middelalderen er rett, vitner de om en mer eller mindre ubrutt skrifttradisjon i enkelte kirker fra kirkenes opprinnelse og fram til i dag. Denne skrifttradisjonen får et brudd idet bruken av runer tar slutt, og ristepraksisene som er samtidige med, og etterfølger, runeristepraksisene, vet vi fortsatt lite om. Borgund stavkirke - og mange andre middelalderkirker - har en enorm mengde bumerker, ulike religiøse symboler og initialer og andre bokstavkombinasjoner risset inn i vegger og dører. Disse vitner om at folk til alle tider har brukt kirkeveggene til å uttrykke seg og til å knytte seg opp mot kirka på ulike måter, men mer forskning er nødvendig for å forstå de yngre uttrykkene og bringe fram ny kunnskap om dem.

Da runene gikk ut av bruk, sank trolig skriftkyndigheten i Norge, for det er lite som tyder på at de som før ristet runer, gikk over til å bruke bokstaver på samme måte. Samtidig har det nok vært en viss folkelig skriftkyndighet også med bokstavskrift i middelalderen (Hagland 2005; Nedkvitne 2005), og brede lag av befolkningen har hatt en lavere grad av skriftkyndighet. De kan for eksempel ha kjent igjen enkelte bokstaver og ord uten selv å kunne skrive (Kleivane 2018: 120-122). Å se funnene av minuskler i lys av kunnskap om skriftkyndighet i seinmiddelalderen vil trolig gi en bedre forståelse av hvem som kan ha ristet minusklene, og hvilken betydning folk har tillagt dem. Videre ville det også være interessant å sammenlikne skriftbruken $i$ kirker i de skandinaviske landene. En slik sammenlikning vil gi bredere innsikt i hvor utbredt de ulike skriftpraksisene som er omtalt her, har vært. I tillegg kan den bidra til bedre forståelse av forskjeller og likheter i skriftkyndigheten på tvers av landegrenser og i rurale og urbane strøk.

Det kan også være fruktbart å se graffiti i kirkene i sammenheng med marginalia i manuskripter. Lena Rogström og Karl G. Johansson (2010: 201-202) peker på likheten mellom håndverkersignaturer med runer og marginalia der skrivere ber Maria om hjelp. En del motiver fra figurativ 
marginalia, blant annet skip, går også igjen i kirkene. Matthew J. Driscoll (2003: 22) påpeker at islandsk marginalia stort sett er skrevet på folkespråket, og at det også er en god del sekulær graffiti i manuskriptene. Han setter den store mengden marginalia på Island i sammenheng med at Island var et fattig samfunn med mangel på pergament og etter hvert papir, men med en høy andel skriftkyndige (ibid.). Dette likner til en viss grad situasjonen i Norge i høymiddelalderen, og dette gjør det interessant å se manuskriptmarginalia og kirkegraffiti i sammenheng. En mer systematisk studie kunne avdekke likheter og forskjeller, og ville kunne si mer om den vestnordiske skriftkulturen fra høymiddelalderen gjennom reformasjonstiden og fram til i dag.

Videre ser det ut til at figurativ og skriftlig graffiti står i nær sammenheng, blant annet i Kviteseid. Også Lerche Nielsen (2019: 21) og Källström (2016: 47) påpeker dette i relativt ferske studier av innskrifter i gotlandske og östergötlandske kirkeinnskrifter. Likevel er det gjort få fors $\varnothing \mathrm{k}$ på å se skrift og figurative motiver sammen. Til en viss grad gjør Plathe dette, for eksempel når hun setter enhjørningmotiver i sammenheng med Maria-monogrammer i nærheten (2019: 254-257). Samtidig er hovedfokuset hennes ikke på innskriftene, men på figurene og hva innskriftene kan fortelle om dem. Som også Källström (2016: 47) påpeker, må en unders $\varnothing$ kelse som ser skriftlige og figurative motiver i sammenheng, være tverrfaglig og bygge på bidrag fra forskere med ulik fagbakgrunn. En tverrfaglig tilnærming er krevende, men vil til gjengjeld kunne gagne alle fagfelt som er opptatt av kirkehistorie.

I denne artikkelen har jeg bare behandlet graffiti fra middelalderen, men graffititradisjonen i flere middelalderkirker har fortsatt uavbrutt fram til i dag. Samtidig blir variasjonen i innskrifter mindre; et overveldende flertall av etterreformatorisk graffiti er bumerker og navn eller initialer med årstall. Det vil være interessant å se nærmere på innskrifter særlig fra reformasjonstida, men også den mer moderne graffitien, og hva disse kan fortelle om historien sett fra enkeltmenneskers perspektiv. Fra 1500-tallet blir det stadig vanligere å datere innskrifter med årstall, og dette gir mulighet til å se nærmere på datering og hvem som ristet innskriftene. En del lokale samlinger av bumerker finnes, men ingen har tidligere sett systematisk på etterreformatoriske initialer og navn.

Det ville også være interessant å se om graffitiinnskrifter henger sammen med ei kirkes status. Mange pilegrimsmål har graffiti; i en norsk kontekst ser vi dette i Nidarosdomen, men pilegrimsgraffiti finnes i hele 
middelalderens kristne verden (se for eksempel Lohmann 2020; Mel'nikova 2016; Nowakowski 2017). Yasin (2015) mener at graffiti på hellige steder over tid bidrar til å forme landskapet de er plassert i. Graffitien står igjen som et vitne om tidligere besøkendes religiøse praksis, og slik bidrar graffitien til å forme nye bes $\varnothing$ kendes oppfatning av og handlinger på stedet (ibid.: 40). Få kirker har alle opprinnelige overflater fra middelalderen intakte; ofte er overflater restaurert, kalket over eller byttet ut ved ombygging. I en del kirker er bare én eller to opprinnelige overflater bevart. Dette gjør det vanskelig å si noe om distribusjonen av innskrifter i dagens kirker, men det er ikke umulig. En slik diskusjon bør ses i lys av kunnskap om religiøs graffiti ellers i middelalderens Europa.

Til tross for mye forskning på runeinnskriftene i norske kirker står flere ubesvarte spørsmål igjen. Å se til andre land og unders $\varnothing \mathrm{ke} \mathrm{inn-}$ skriftsgrupper som til nå har fătt lite oppmerksomhet, kan $\varnothing$ ke forstålsen av hvordan menneskene som har søkt til kirkene, har forholdt seg til dem fra middelalderen og helt fram til i dag.

\section{Litteratur}

Anker, Leif. 2005. Kirker i Norge. Middelalder i tre. Stavkirker, Kirker $i$ Norge 4. Oslo: ARFO, forlag for arkitektur og kunst.

Barnes, Michael P. 1994. The Runic Inscriptions of Maeshowe, Orkney, Runrön 8. Uppsala: Institutionen för nordiska språk, Uppsala universitet.

-. 2012. Runes: A Handbook, Woodbridge: Boydell Press.

Blindheim, Martin. 1985. Graffiti in Norwegian stave churches c. 1150c. 1350. Oslo: Universitetsforlaget.

Bollaert, Johan. Under arbeid. Visuality and literacy in medieval Norwegian epigraphy. A comparative study of Runic and Roman alphabetic Inscriptions. Upubl. doktoravhandling, Universitetet i Oslo.

Bæksted, Anders. 1944. Norges innskrifter med de yngre runer, utgitt for Kjeldeskriftfondet, med hjelp i forarbeider av Sophus Bugge, Oluf Rygh og Ingvald Undseth ved Magnus Olsen. Første bind. Oslo 1941. X + 244pp., 2 pl. [bokmelding]. Arkiv för nordisk filologi LVII, 256268.

Champion, Matthew. 2016. Medieval Graffiti: The Lost Voices of England's Churches. London: Ebury Press. 
Danmarks runeindskrifter (DR). Bind I-III, red. Lis Jacobsen \& Erik Moltke. København: Munksgaard, 1941-1942.

Diplomatarium Norvegicum (DN). Bind I-XXIII, red. Chr. Lange mfl. Oslo: Seksjon for kildeutgivelse, 1847-2011.

DN (se Diplomatarium Norvegicum).

DR (se Danmarks runeindskrifter).

Driscoll, Matthew James. 2003. Postcards from the edge. An overview of marginalia in Icelandic manuscripts. Variants II/III, 21-36.

Dybdahl, Audun. 2002. Nidaros Domkirkes og geistlighets kostbarheter. Belyst ved 17 skriftlige kilder 1307-1577 med oversettelser og kommentarer, Skrifter 13. Trondheim: Tapir.

Engtr $\varnothing$, Dag- $\varnothing$ yvind H. 2009. Runeinnskriftene på Nidarosdomen. Trondhjemske samlinger 2009, 91-114.

Fulton, Rachel. 2006. "Taste and see that the Lord is sweet" (Ps. 33:9): The Flavor of God in the Monastic West. The Journal of Religion 86: 2, 169-204.

Gjesdahl, Tone Sofie. 1969. Hopperstadciboriet. Upubl. magistergradsavhandling, Universitetet i Oslo.

Goehring, James E. 2015. Exploring the Wadi Sheikh Ali. Photographic Evidence from the 1980 Survey. I: Invest Your Humanity: Celebrating Marvin Meyer, red. Julye Bidmead \& Gail J. Stearns, 69-90. Eugene, Oregon: Pickwick Publications.

Gustavson, Helmer. 1991. Sockenkyrkan som skriftdokument. I: Kyrka og socken i medeltidens Sverige. Studier til det medeltida Sverige 5, red. Olle Ferm, 545-562. Stockholm: Riksantikvarieämbetet.

-. 1994. Runorna och det latinska språket. I: Runmärkt. Från brev till klotter. Runorna under medeltiden, red. Solbritt Benneth mfl., 127-141. Stockholm: Carlssons bokförlag.

Hagland, Jan Ragnar. 2005. Literacy i norskseinmellomalder. Oslo: Novus forlag.

Holmqvist, Karen Langsholt. 2018. Names and Prayers. Expressions of Self in the Medieval Inscriptions of the Nidaros Cathedral Walls. Collegium Medievale 31 (2018), 103-149.

-. 2020a. The Creation of Selves as a Social Practice and Cognitive Process. A Study of the Construction of Selves in Medieval Graffiti. I: Approaches to the Medieval Self. Representations and Conceptualizations of the Self in the Textual and Material Culture of Western Scandinavia, 
c. 800-1500, red. Stefka G. Eriksen mfl., 301-323. Berlin: Walter de Gruyter.

-. 2020b. Mikill ofláti 'a great show-off'. The selves in the runic inscriptions of Maeshowe, Orkney. Viking and Medieval Scandinavia 16 (2020), 63-102.

Imer, Lisbeth M. 2017. Peasants and Prayers. The inscriptions of Norse Greenland, Publications from the National Museum 25. Odense: University Press of Southern Denmark.

-. 2018. Rigets runer, 100 danmarkshistorier. Aarhus: Aarhus Universitetsforlag.

Imer, Lisbeth M. \& Rikke Steenholt Olesen. 2018. In the beginning was the Word...: New finds of lead amulets in Denmark. I: Epigraphy in an Intermedial Context, red. Alessia Bauer mfl., 123-155. Dublin: Four Courts Press.

Jones, Annette. 2010. Portals to the Past. Distribution Patterns in Stave Church Inscriptions [paper preprint]. I: The 7th International Symposium on Runes and Runic Inscriptions, 9-14 August, Oslo.

Jones, Annette. Uten årstall. Why Knotrune? https://knotrune.wordpress.com/why-knotrune/. Sist bes $\varnothing \mathrm{kt}$ 31.8.2021.

Kjesrud, Karoline. 2015. Conceptions of the Virgin Mary in Medieval Western Scandinavia. I: Words and Matter. The Virgin Mary in Late Medieval and Early Modern Parish Life, red. Jonas Carlquist \& Virginia Langum, 87-103. Scripta minora 24. Stockholm: Sällskapet Runica et Mediaevalia.

-. 2018. Marian Representations. I: Handbook of Pre-Modern Nordic Memory Studies: Interdisciplinary Approaches, red. Jürg Glauser mfl., 477-485. Berlin: Walter de Gruyter.

Kleivane, Elise. 2018. Epigraphic Ave Maria as evidence of medieval literacy. I: Epigraphy in an Intermedial Context, red. Alessia Bauer m.fl., 101-122. Dublin: Four Courts Press.

-. 2019. To menn og Ave Maria i Hamarkaupangen. Maal og Minne 2019: 2, 69-99.

KLNM (se Kulturhistorisk leksikon for nordisk middelalder fra vikingtid til reformasjonstid).

Knirk, James E. 1986. Runeinnskriftene i B $\emptyset$ gamle kyrkje. Telemark historie. Tidsskrift for Telemark historielag 7, 71-81.

-. 1989a. Arbeidet ved Runearkivet, Oslo. Nytt om runer. Meldingsblad om runeforskning 4 1989, 6-9. 
-. 1989b. Arbeidet ved Runearkivet, Oslo. Nytt om runer. Meldingsblad om runeforskning 3(1988), 8-10.

-. 1991. Arbeidet ved Runearkivet, Oslo. Nytt om runer. Meldingsblad om runeforskning 6(1991), 13-16.

-.1994. Learning to Write with Runes in Medieval Norway. I: Medeltida skrift-och språkkultur. Nordisk medeltidsliteracy i ett diglossiskt och digrafiskt perspektiv II. Nio föreläsningar från ett symposium i Stockholm våren 1992 med inledning av Barbro Söderberg, red. Inger Lindell, 169212. Stockholm: Sällskapet Runica et Mediævalia, Medeltidsseminariet och Institutionen för nordiska språk vid Stockholms universitet.

-. 1998. Runic Inscriptions Containing Latin in Norway. I: Runeninschriften als Quellen interdisziplinärer Forschung, red. Klaus Düwel, 476-507. Berlin: Walter de Gruyter.

Kolsrud, Oluf, utg. 1952. Messuskýringar. Liturgisksymbolikk frå den norskislandske kyrkja i millomalderen. Fyrste heftet. Oslo: Norsk Historisk Kjeldeskrift-Institutt, i hovudkommisjon hjå Jacob Dybwad.

Kraack, Detlev \& Peter Lingens. 2001. Bibliographie zu bistorischen Graffiti zwischen Antike und Moderne. Krems: Medium Aevum Quotidianum.

Kuhn, Stephan. 2020. Marian Tabernacles on Main Altars: Norwegian Thirteenth-Century Altar Decorations in their European Context. Medievalia 31: 1, 101-128.

Kulturbistorisk leksikon for nordisk middelalder fra vikingtid til reformasjonstid (KLNM). Bind I-XXI. København: Rosenkilde og Bagger, 19561978.

Källström, Magnus. 2016. Runor i puts. Några nyfynd från Gotland och Västergötland. META Historiskarkeologisk tidskrift 16, 35-49.

Lerche Nielsen, Michael. 2019. Skriften på væggen. Kalenderindskrifter og en allegorisk lønruneformel fra Gotland. Arkiv för nordisk filologi 134, 5-23.

Liestøl, Aslak. 1954. A. Liest $\varnothing l$ ls befaringsrapport N392-N412. Rapport i Runearkivet.

Lohmann, Polly. 2020. Historical Graffiti. The State of the Art. JEMS. Journal of Early Modern Studies 9, 37-56.

Lovata, Troy R. \& Elizabeth Olton, ed. 2015. Understanding Graffiti. Multidisciplinary Studies from Prehistory to the Present. Walnut Creek, California: Left Coast Press. 
Lundhaug, Hugo \& Lance Jenott. 2015. The Monastic Origins of the Nag Hammadi Codices, Studies and Texts in Antiquity and Christianity 97. Tübingen: Mohr Siebeck.

Mel'nikova, Elena A. 2016. A New Runic Inscription from Hagia Sophia Cathedral in Istanbul. Futhark 7, 101-110.

Moltke, Erik. 1985. Runes and their Origin. Denmark and Elsewhere. Kфbenhavn: Nationalmuseets forlag.

Nedkvitne, Arnved. 2005. B $\emptyset$ nder og skrift i norsk middelalder. Historisk tidsskrift 84, 97-106.

NIyR (se Norges innskrifter med de yngre runer).

Nordby, K. Jonas. 2003. Arbeidet ved Runearkivet, Oslo. Nytt om runer. Meldingsblad om runeforskning 16(2001), 13-18.

-. 2018. Lønnruner: Kryptografi i runeinnskrifter fra vikingtid og middelalder. Upubl. doktorgradsavhandling, Universitetet i Oslo.

Norges innskrifter med de yngre runer (NIyR). Bind I-VI, red. Magnus Olsen m.fl. Oslo: Norsk historisk kjeldeskrift-institutt, 1941-.

Nowakowski, Paweł. 2017. 'And there, unworthy as I was, I wrote the names of my parents'. U schytku starożytności - Studia źródtoznawcze. Late Antiquity - Studies in Source Criticism XVI (2017), 229-255.

Pernler, Sven-Erik. 1994. 'Lafrans gjorde denna kyrka'. Runor i kyrkomiljöer. I: Runmärkt. Från brev till klotter. Runorna under medeltiden, red. Solbritt Benneth m.fl., 105-118. Stockholm: Carlssons bokförlag.

Plathe, Sissel F. 2019. Gotikkens kalkmalerier. De oversete dekorationer i Danmarks kirker, København: Gads forlag.

Reckwitz, Andreas. 2002a. The Status of the 'Material' in Theories of Culture. From 'Social Structure' to 'Artefacts'. Journal for the Theory of Social Behaviour 32: 2, 195-217.

-. 2002b. Towards a Theory of Social Practices. A Development in Culturalist Theorizing. European Journal of Social Theory 5: 2, 243-263.

Rogström, Lena \& Karl G. Johansson. 2010. De bohuslänska runinskrifterna. Varför är de viktiga? I: Språkhistoria. Hur och för vem?, red. Erik Magnusson \& Lena Rogström, 195-204. Meijerbergs arkiv för svensk ordforskning 36. Göteborg: Meijerbergs arkiv för svensk ordforskning, Göteborgs universitet.

Rozhdestvenskaja, Tatjana. 2012. Written Culture of Medieval Novgorod in the Light of Epigraphy. I: Epigraphic Literacy and Christian Identity. Modes of Written Discourse in the Newly Christian European 
North, red. Kristel Zilmer \& Judith Jesch, 251-272. Utrecht Studies in Medieval Literacy 4. Turnhout: Brepols.

Rygh, Oluf. 1919. Gaardnavne i Nordre Bergenshus amt, Norske Gaardnavne. Oplysninger samlede til brug ved matrikelens revision. Kristiania: W. C. Fabritius \& sønner A/S.

Samnordisk runtextdatabas. http://www.nordiska.uu.se/forskn/samnord.htm. Lastet ned 13.9.2019.

Schatzki, Theodore R. 2001a. 3: Practice Mind-ed Orders. I: The Practice Turn in Contemporary Theory, red. Theodore R. Schatzki m.fl., 5063. New York: Routledge.

-. 2001b. Introduction: Practice Theory. I: The Practice Turn in Contemporary Theory, red. Theodore R. Schatzki m.fl., 10-23. New York: Routledge.

Schulte, Michael. 2020. Tistel-mistel-formelen i vikingtid og nordisk middelalder. Form, funksjon og symbolverdi. Maal og Minne 112: 2, 97126.

Seim, Karin Fjellhammer. 1997. Om garpegenitiven som i stedet var et kjønnsorgan, og andre 'utuktige' leksemer i norske runeinnskrifter. I: Språket er målet: Festskrift til Egil Pettersen på 75-årsdagen 4. mars 1997, red. Jarle Bondevik m.fl., 178-187. Bergen: Alma Mater.

- 1998 . De vestnordiske futhark-innskriftene fra vikingtid og middelalder. Form og funksjon. Upubl. doktoravhandling, Norges teknisknaturvitenskapelige universitet.

- 2005. Rapport om runefunn i Stein kirke på Byneset, Trondheim. Rapport i Runearkivet.

Sidselrud, Agnieszka Ewa. 200o. Religion og magi i nordisk middelalder: 'Ave Maria' og 'Pater Noster' med runer - bønn eller magisk formula? Upubl. masteravhandling, Universitetet i Oslo.

Skånberg, Tuve. 2003. Glömda gudstecken. Från fornkyrklig dopliturgi till allmogens bomärken. Lund: Lunds Universitets Kyrko-historiska Arkiv.

Solem, Dag- $\varnothing$ yvind Engtr $\varnothing$, Mille Stein \& Fredrik Berg. 2017. Hopperstadciboriet. 3D-scanning og C14-analyse (NIKU oppdragsrapport 143/2017).

Spurkland, Terje. 2001. I begynnelsen var FחPFRく: Norske runer og runeinnskrifter. Bergen: Fagbokforlaget.

Stein, Mille \& Merete Winness. 2011. Hopperstad stavkirke. Behandling av kunst og inventar. Forprosjekt (NIKU Oppdragsrapport 46/2011). 
Syrett, Martin. 2002. The Roman-Alphabet Inscriptions of Medieval Trondheim I-II, Skrifter 13. Trondheim: Tapir.

Thun, Terje, Jan Michael Stornes, Thomas Seip Bartholin \& Helene Løvstrand Svarva. 2016. Dendrochronology brings new life to the stave churches. Dating and material analysis. I: Preserving the stave churches. Craftsmanship and research, red. Kristin Bakken, 91-116. Oslo: Pax.

Turner, Mark. 2014. The Origin of Ideas. Blending, Creativity and the Human Spark, New York: Oxford University Press.

Waldispühl, Michelle. 2019. Roman and Runic in the Anglo-Saxon Inscriptions at Monte Sant'Angelo: A Sociolinguistic Approach. Futbark 9-10 (2018-2019), 135-158.

Yasin, Ann Marie. 2015. Prayers on Site. The Materiality of Devotional Graffiti and the Production of Early Christian Sacred Space. I: Viewing Inscriptions in the Late Antique and Medieval World, red. Antony Eastmond, 36-6o. New York: Cambridge University Press.

Zilmer, Kristel. 2013. Christian Prayers and Invocations in Scandinavian Runic Inscriprions from the Viking Age and the Middle Ages. Futhark 4, 129-171.

-. 2016. Words in Wood and Stone. Uses of Runic Writing in Medieval Norwegian Churches. Viking and Medieval Scandinavia 12, 199-227. -. under publisering. Identities. I: A Cultural History of Media in the Middle Ages, red. Carol Symes. London, Oxford: Bloomsbury Academic.

Öberg, Christina Sandquist. 2017. Senmedeltida textskatti uppländska kyrkor. Samtliga bevarade språkband med kommentarer och analyser, KVHAA Handlingar historiska serien. Stockholm: Kungl. Vitterhets historie och antikvitets akademien.

\section{Abstract}

The article discusses runic and Roman alphabet graffiti in Norwegian medieval churches and sees script type and language as two variables for the carvers' expression of self. As examples, inscriptions from the stave churches Borgund and Hopperstad are used. Hopperstad only has runic inscriptions, which are distributed spatially and thematically in the church room. In the chancel, we have formulaic religious utterances in Latin; in 


\section{Karen Langsholt Holmqvist}

the nave vernacular inscriptions which are varied and reader oriented, with both play and religious utterances. The carvers direct themselves towards the social fellowship and the church as a religious place of assembly. Borgund is characterised by highly literate carvers who use both ornate runes and Roman alphabetic letters to create textual and visual effects in the inscriptions. The article presents several newly discovered minuscules from Borgund, and these are compared to Roman alphabetic inscriptions, particularly with minuscules, in other churches in Norway and Denmark, and are interpreted as possibly religious utterances. At the same time, the minuscules may also have been carved as an exercise or ornament, and they can thus have several layers of meaning.

Karen Holmqvist Norsk institutt for kulturminneforskning og Universitetet i Oslo Institutt for lingvistiske og nordiske studier

Sidsel Sidsærks vei 17 NO-0956 Oslo karen.holmqvist@niku.no karen.holmqvist@gmail.com 